\title{
Relational capital for shared vision in innovation ecosystems
}

\author{
Martha G Russell ${ }^{1 *}$, Jukka Huhtamäki ${ }^{2}$, Kaisa Still ${ }^{3}$, Neil Rubens ${ }^{4}$ and Rahul C Basole ${ }^{5}$
}

\author{
* Correspondence: \\ martha.russell@stanford.edu \\ ${ }^{1}$ mediaX at Stanford University, \\ Cordura Hall, 210 Panama Street, \\ Stanford, CA 94305-4115, USA \\ Full list of author information is \\ available at the end of the article
}

\begin{abstract}
This paper provides an evidence-based approach to understanding the relationship infrastructure of spatially defined innovation ecosystems in three metropolitan areas. With the Triple Helix framework, the ecosystem perspective, and shared vision for transformation initiatives, we explore relationships as structure in the metropolitan areas of Austin, TX; Minneapolis, MN; and Paris, France. Network metrics are interpreted as indicators of relational capital; and network visualizations reveal distinct patterns of relational space that structure business ecosystems at the enterprise, growth, and startup levels in each geographic area. We illustrate that network metrics, relationship indicators, and their visualization can be valuable resources for quantitatively and qualitatively investigating and analyzing the complexities of engagement, agility, vitality, linking, and embeddedness in innovation ecosystems. We suggest that data-driven indicators of relational capital may be used for network orchestration, evidence-based policy, and the development of shared vision in spatially defined business ecosystems.

Keywords: Ecosystem; Networks; Innovation; Business; Metropolitan; Relationships; Visualization
\end{abstract}

Spanish: El capital relacional por una visión compartida en los ecosistemas de innovación.

Resumen: Este artículo ofrece un enfoque basado en evidencias que permite comprender la infraestructura de relaciones en los ecosistemas de innovación de tres áreas metropolitanas. Empleando el marco de trabajo de Triple Hélice, la perspectiva de ecosistema y una visión compartida por iniciativas de transformación, exploramos las relaciones, entendidas como estructura, en las áreas metropolitanas de Austin (Texas, EE.UU.), Minneapolis (Minnesota, EE.UU.) y París (Francia). Los datos de red son interpretados como indicadores de capital relacional y las visualizaciones de red revelan patrones claros de espacio relacional que estructuran los ecosistemas de empresas, crecimiento y niveles de startup en cada área geográfica. Mostramos que las métricas de red, los indicadores de relación y sus visualizaciones pueden ser valiosos recursos a la hora de investigar y analizar tanto cuantitativa como cualitativamente la diversidad de compromiso, agilidad, vitalidad, conexión e implantación en los ecosistemas de innovación. Sugerimos que los indicadores de datos relacionados con el capital relacional pueden ser empleados para la orquestación de redes, políticas de evidencia y el desarrollo de visiones compartidas en ecosistemas empresariales delimitados espacialmente.

\section{Springer}

(c) 2015 Russell et al.; licensee Springer. This is an Open Access article distributed under the terms of the Creative Commons Attribution License (http://creativecommons.org/licenses/by/4.0), which permits unrestricted use, distribution, and reproduction in any medium, provided the original work is properly credited. 
French: Le capital relationnel pour une vision partagée des écosystèmes d'innovation.

Resumé: Cet article nous offre une approche fondée sur des preuves pour comprendre l'infrastructure relationnelle d'écosystèmes d'innovation spatialement définis dans trois régions métropolitaines. Dans le cadre de la Triple Hélice, la perspective de l'écosystème et une vision partagée pour des initiatives de transformation, l'auteur explore les relations comme structure, dans les régions métropolitaines de Austin, TX, Minneapolis, MN, et Paris, France. Les métriques du réseau sont interprétées comme des indicateurs de capital relationnel; et les visualisations de ces réseaux révèlent différents modèles de relations spatiales qui structurent les écosystèmes d'affaires dans les entreprises ainsi que la croissance et les niveaux de startup dans chaque région géographique. L'article montre que les métriques du réseau, les indicateurs relationnels et leur visualisation peuvent être des ressources valables pour examiner quantitativement et qualitativement et analyser les complexités de l'engagement, l'agilité, la vitalité, le lien et l'enracinement dans les écosystèmes d'innovation. II est suggéré que les indicateurs de capital relationnel basés sur des données peuvent être utilisés pour orchestrer le réseau, mettre en œuvre une politique fondée sur des preuves, et développer une vision partagée dans des écosystèmes d'affaire définis spatialement.

Portuguese: Capital Relacional para uma visão partilhada dos ecossistemas de inovação.

Resumo: Esse artigo fornece uma abordagem baseada na evidência para compreender o relacionamento entre infraestrutura e espacialidade definidas pelos ecossistemas de inovação em três áreas metropolitanas. Com a estrutura teórica da Hélice Tríplice, a perspectiva de ecossistema e uma visão compartilhada para a transformação de iniciativas nós exploramos os relacionamentos como uma estrutura, nas áreas metropolitanas de Austin, TX, Minneapolis, MN, e Paris, França. As métricas de network são interpretadas como indicadores do capital relacional e a visualização das networks revelam distintos padrões do espaço relacional que estrutura os ecossistemas de negócios das empresas, seu crescimento e os níveis de startups em cada área geográfica. Nós ilustramos as métricas de network, os indicadores de relacionamento e como suas respectivas visualizações podem ser recursos valiosos para investigar qualitativamente e quantitativamente e também analisar as complexidades de engajamento, agilidade, vitalidade, associação e enraizamentos nos ecossistemas de inovação. Nós sugerimos que os indicadores de capital relacional baseados em dados podem ser utilizados para orquestrar a network, politicas baseadas evidências, e o desenvolvimento de uma visão compartilhada da espacialidade definida pelos ecossistemas de negócios.

\section{Multilingual abstract}

Please see Additional file 1 for translation of the abstract into Arabic.

\section{Background}

With a rapidly changing business environment, fast product cycles, and decreasing average life expectancy of today's companies, innovation managers feel a sense of urgency to find effective methods and techniques to understand and manage the complexity of their business ecosystems (Adner 2012). Cities and metropolitan areas are spatially defined elements of innovation ecosystems, and regional development efforts 
aim to stimulate innovation within the local community as well as increasing their contributions to national economies (OECD 2014). In this paper, we present a novel approach for gaining insights to accelerating business development with emphasis on relationships. Hence, we address some of the challenges of measuring and managing innovation, especially the call for evidence-based policy (NESTA 2008) and the emphasis on innovation dynamics (Milbergs 2007).

Scholars have focused inquiry on the diverse elements of innovation and economic growth at global, national, regional, metropolitan, and city levels, as well as at the level of individual organizations. Recent innovation studies have highlighted the importance of relationships among companies, their leadership individuals, and their financial organizations in contributing to the development of innovation in technology parks (Gibson et al. 1992), innovation ecosystems for regional economic development programs (Russell 1995; Still et al. 2014a), business acceleration programs (Huhtamäki et al. 2012), and business network visualization methods (Basole 2014).

An innovation ecosystem refers to the inter-organizational, political, economic, environmental, and technological systems through which a milieu conducive to business growth is catalyzed, sustained, and supported. A dynamic innovation ecosystem is characterized by a continual realignment of synergistic relationships that promote growth of the system. In agile responsiveness to changing internal and external forces, knowledge, capital, and other vital resources flow through these relationships (Russell et al. 2011). Adapted from the biological sciences, an ecosystem perspective offers insights on the relationship dimension of innovation. The innovation ecosystem perspective is based on the premise that communities consist of a heterogeneous and continuously evolving set of constituents that are interconnected through a complex, global network of relationships. These constituents cocreate value and are interdependent for survival (Moore 1996; Iansiti and Levien 2004; Basole and Rouse 2008; Russell et al. 2011).

Evidence-based decision-making has been promoted as a means to reduce the risk of bad decisions (Burwell et al. 2013; Seelos and Mair 2012). In order to base decisions on evidence, data is needed. The collection of primary data for business network research is time-consuming and costly. Outcome measures for intervention programs frequently point to time-specific events and actors as indicators of progress toward transformation, which may require decades to be realized. Current data-driven analysis and evaluation tools tend to rely on curated data, standardized over time with baked-in data policies and classifications that persist in practice long after real-world semantics have shifted to new categories (Basole et al. 2015).

Change strategists want to know which systemic factors may produce counterintuitive results in the short-term and what time is required to see the lasting impact in the system. Community leaders want insights on how policies and programmatic interventions can be orchestrated to facilitate transformation of a business ecosystem. Many of the quantitative ratings and rankings of geographic areas draw on expert opinion to characterize innovation. They often focus on a single perspective of the system and seldom include more than anecdotal information about the relationships among business leaders. Transformation goals vary across communities, though generally 'by stimulating co-operation among the different actors in the innovation system, policy makers expect that the innovation potential can be better exploited in existing and new firms, in research, and in society as a whole' (OECD 2001). A map of the relationships through which trust can 
accelerate collaboration is needed to show interim progress toward achieving future outcomes of the shared vision.

As the nature and landscape of innovation have evolved, there has been a need to evolve commensurate innovation indicators and metrics. In this analysis, we seek to test whether the innovation character of spatially defined areas can be reflected in datadriven, evidence-based indicators, and visual patterns of relationship networks in each area. We present an evidence-based approach to understanding the relationship infrastructure of spatially defined innovation ecosystems. With relationship maps at three levels of business activity, we reveal the structures of relationships through which information, talent, and financial resources flow as a basis for shared vision about the future. We propose data-driven indicators of relational capital that may be used for network orchestration and evidence-based policy in spatially defined business ecosystems.

Our approach is based on the ecosystem perspective, which is adapted from the biological/ecological sciences, drawing upon the foundational studies of regional clusters, the Technopolis Wheel and the Triple Helix. Converged through the Innovation Ecosystems Transformation Framework (IETF) (Russell et al. 2011), our approach views metropolitan communities as innovation ecosystems, consisting of a heterogeneous and continuously evolving set of constituents that are interconnected through a complex, global network of relationships; these constituents co-create value and are interdependent for survival (Moore 1996; Iansiti and Levien 2004; Basole and Rouse 2008). Our analytical method addresses ecosystems as networks of relationships, using a network analysis approach: when collective gains are sought at the network level, change agents seek to orchestrate networks and manage their growth (Paquin and Howard-Grenville 2013; Ritala et al. 2013). An earlier study emphasizing the structure of a network toward understanding the performance of regional clusters in Japan (Kajikawa et al. 2010) concluded that 'despite the importance of interfirm networks, we currently have fewer tools to investigate it and therefore less knowledge on detailed structure of it'. In this paper, we embrace this challenge.

The structure of the paper is as follows. Following a review of key concepts of innovation ecosystems and the relationship dimension of innovation, we describe our evidence-based data-driven process for measuring and visualizing innovation ecosystems. We implement this approach by concentrating and elaborating on one strand of the Triple Helix - corporate and business relationships - in contrasting three metropolitan areas: the Austin Texas Metropolitan Area, the Minneapolis/St. Paul (Twin Cities) Minnesota Corridor, and the Greater Metropolitan areas of Paris France. We present indicators and visualizations of relational capital based on network metrics. We conclude with a discussion of challenges and opportunities that we hope will stimulate collaborative discovery for new insights within the Triple Helix community and across the many communities with which its influencers have relationships.

\section{Innovation in metropolitan areas}

Metropolitan areas are critical for job creation, revenue generation, and economic growth. Regional policies, targeted strategies, and investments are needed to help metropolitan areas build on their distinct and concentrated assets, and national policies and programs are needed to help regions and metropolitan areas (Katz et al. 2010). One example of the importance of metropolitan areas is offered by the Brookings (2014) stating that 'U.S. 
metropolitan areas are now home to 83 percent of American citizens, serving as incubators of innovation and entrepreneurship that can help generate quality jobs and spur sustainable economic growth' (http://www.brookings.edu/research/topics/u-smetro-areas).

\section{The relational dimension of innovation ecosystems}

Addressing innovation ecosystems as networks allows scholars and practitioners to study their complexity, providing a means for mapping, monitoring and managing the ecosystem components. In recent years, metaphors for ecosystems have been promoted. Padgett and Powell (2012) describe autocatalysis as a chemical metaphor for self-organization and emergence of networks. Hwang and Horowitt (2012) describe the ecosystem as a rainforest that includes cycles of birth, growth, death, and regeneration, as well as conditions for homeostasis or dynamism.

Identifying various stakeholders and their relationships as assets and liabilities for technology-based economic development has been the subject of many scholars' work. Emphases have been on knowledge spillovers due to regional clustering (Marshall 1920), on specialized activity clusters (Schumpeter 1942; Porter 1990), and on the interrelations of organizational structures in a paradox of simultaneous competition and cooperation networks across different community organizations and institutions (Ouchi and Wilkins 1985; Smilor and Wakelin 1990). Studies of information dissemination in small, heterogeneous agricultural communities focused on their key opinion leaders and influencers (Rogers 1965; Oreszczyn et al. 2010). More recent economic development studies have focused on the synergistic advantages within the regional cluster (Saxenian 1994; Gibson and Butler 2014), the role of financing relationships as infrastructure (Huhtamäki et al. 2011), and the importance of culture as an enabler (Florida 2012). Ubiquitous global communications, coupled with the concept of open innovation (Chesbrough 2003) have escalated the imperative for globalization of business relations and renewed the focus on system-level effects (Hwang and Horowitt 2012) and relational capital (Still et al. 2013b).

\section{Triple Helix}

To facilitate the disciplined study and the broad understanding of innovation influences, the Triple Helix model has acknowledged the contributions of multiple stakeholders. It has categorized these influencers into three (hence Triple) institutional strands within the social context of university-industry-government relations (Etzkowitz and Leydesdorff 1995; Etzkowitz and Leydesdorff 2000). The Triple Helix model is defined by a complex set of organizational ties among overlapping spheres that may cross the boundaries between them (Leydesdorff and Etzkowitz 1998). The Triple Helix model contributes value to analyzing innovation in a knowledge-based economy, in which knowledge flows, interactions, and communications take place within 'hyper-networks of organizations', and in which participants at one level of networking can use collaborations or boundaries from other levels as resources (Leydesdorff and Etzkowitz 1998).

Scholars have recommended including financing organizations (Moody and White 2003; Huhtamäki et al. 2011) as part of the social and organization context of business networks. And, Leydesdorff (2012) has introduced 'society' and 'public' into the Triple 
Helix context, adding an emphasis on interactions, and opening the conceptual opportunities for additional helices, the N-tuple of helices, to be added to the Triple Helix model.

\section{Technopolis Wheel}

The key role of first and second level influencers in leveraging assets of public and private sectors networks was formalized in the framework of the Technopolis Wheel (Smilor et al. 1988). This framework recognized that a network of institutional alliances accelerates regional development (Smilor and Wakelin 1990). The Technopolis Wheel emphasizes that each firm is embedded in a regional ecosystem that includes public and private sectors, in which networking and collaboration are key to the community and regional dynamics of new venture creation (Kozmetsky 1993). It was born in the early days of technopolis programs and technology incubators, and it sought to reinvent business through community collaboration:

'The solutions to many critical issues and problems now demand an integrated, holistic and flexible approach that blends technology, management, and scientific, socio-economic, cultural and political ramifications in an atmosphere of profound change and extreme time compression' (Kozmetsky 1993).

Networks of community organizations and influentials have been recognized as a critical factor in describing the culture and capacity of a region (Florida 2012; Saxenian 2007; Rosenberg 2002; Nishizawa 2011). With ubiquitous communications adopted in the past decade, time pressures have intensified (Yotsumoto 2010), business globalization has accelerated, and institutional structures have diversified (Mrak 2000). These changes have served to blur the boundaries of traditionally defined sectors and increase the importance and influence of formal and informal collaboration networks.

\section{Interfirm networks and business ecosystems}

With the complexity of product and service development and with markets now becoming increasingly disintegrated vertically and horizontally, there have been both a need and an opportunity for new perspectives that conceptualize interfirm relations in innovation (Iansiti and Levien 2004) and identify pathways by which relationships affect business success (Svendsen et al. 2001). The formation of networks and alliances has been particularly beneficial in technology industries as this approach has allowed firms to share risks in development and obtain access to synergistic knowledge (Eisenhardt and Schoonhoven 1996; Adner 2012). Studies have shown that interfirm networks are an effective organizational form to improve firm performance, speed of innovation, and organizational learning (Ahuja 2000; Gulati et al. 2000). Other studies have adopted a complex networked systems perspective to examine why, when, and how interfirm networks and alliances form and change (Gulati et al. 2000). Mechanisms for multiple, independent paths to link structurally cohesive actors in ways that could enable transfer of resources and coordination of activity have also been demonstrated (Moody and White 2003; Kajikawa et al. 2010).

Concepts of business ecosystems represent an offshoot of interfirm networks. Business ecosystems are comprised of heterogeneous and continuously evolving sets of firms that are interconnected through a complex, global network of relationships 
(Basole et al. 2015). As such, they consist of interdependent firms that form symbiotic relationships to create and deliver products and services (Basole and Rouse 2008; Dougherty and Dunne 2011). The complex networked systems approach has also been used to study value networks and ecosystems in a variety of industries (Adner 2012; Basole and Rouse 2008; Rosenkopf and Schilling 2008). This view combines both the resource dependency and the coalition perspective and suggests that interfirm networks are complex systems characterized by co-evolving actors engaged in collaboration and co-opetition (Iansiti and Levien 2004; Kajikawa et al. 2010) as well as the emergence of collective invention (Powell and Giannella 2010).

\section{Methods of evaluating innovation}

The need for better measures in innovation is central to the generation, diffusion, and exploitation of knowledge and the subsequent economic growth, development, and the well-being of nations (OECD 2005). The conceptual underpinnings of the Innovation Ecosystem approach evolve from the Technopolis model and the Triple Helix model, synthesizing from their theories as well their practical implications. Additionally, the innovation ecosystem concept is a result of theoretical extensions of work in inventor networks (Powell and Giannella 2010) and of interfirm networks, alliances, and innovation (Gulati 1998; Moore 1993; Oliver 1990) as well as the importance of human networks (Hwang and Horowitt 2012), all recognizing the systemic approach. Hence, the term innovation ecosystem has been applied to address the complexities related to innovation (Durst and Poutanen 2013) and the importance of relational capital (Still et al. 2014a).

\section{Innovation indicators and rankings}

Much of the current support for decision makers and policy makers within the context of metropolitan areas highlights traditional innovation indicators such as GDP job growth as well as specific R\&D-related measures such as R\&D expenditures and patent activity. For example, OECD indicators for regions include demographic statistics, innovation indicators ( $R \& D$ expenditures, education, and patenting activity), labor statistics, regional accounts (Gross Domestic Product indicators), and social indicators (for example, for health and safety; OECD 2014; http://stats.oecd.org/).

There are also many composite indicators that address innovation in regional, metropolitan, and city levels. Oftentimes, these are presented in forms of ranking lists, based on selected variables and their weighted importance, and they are based on analysis on data, for example, from Oxford Economics, Moody's Analytics, and the U.S. Census Bureau. These lists or rankings examine the role of metropolitan areas in driving economies and the desire to create a platform for cities and metropolitan areas to boost competitiveness in the global marketplace (Brookings 2014). ${ }^{\mathrm{a}}$

In addition, there are many lists that are more limited and whose scientific and statistical bases are not quite so clear. For example, the list of most technologically innovative cities (http://www.citiesjournal.com/16-most-technologically-innovative-cities-in-the-world/) does not state the origins nor how the data were analyzed. The list for the most inventive cities is based on patent intensity according to OECD statistics (Pentland 2013). The rigorous analysis of information submitted by nominees for the intelligent communities awards is not described (https://www.intelligentcommunity.org/). 
Furthermore, many of the indicators as well as their indices geared toward innovation and economic growth are incomplete, not addressing the intangibility of innovation, and lacking in detail and timeliness (Still et al. 2013b). For example, using patents as indicators has been criticized because their value is typically realized only after 10 years, and they represent only one aspect of knowledge-based contributions (Langford et al. 2006). Such time-constrained indicators may miss important cues about the rapid growth of fast-scaling digital technology companies such as Supercell in 2014.

\section{Relationship focus - a critical element}

In regional and metropolitan areas, local and regional development deals, alliances, and partnerships frequently include actors from the community and civil society as well as from formal organizations in the public, in both profit, and not for profit sectors. Though it is generally agreed that relationships are important (following the old adage 'It is not what you know but who you know'), there is considerable confusion over exactly what outcomes are actually attributable to relationships, and there is agreement that the evaluation of relationships is complex (Cropper et al. 2008). A relationship focus has been largely missing from innovation indicators and rankings, as illustrated in the list of the 31 segments of indicators of innovative cities; in which none of the 162 indicators includes the word 'relationship' (Figure 1).

A clear step forward can be found in the newest version of the Oslo Manual, which provides guidelines for collecting and interpreting innovation data. It includes a recommendation on how to measure the linkages as 'each linkage connects the innovating enterprise to other actors in the innovation system: government laboratories, universities, policy departments, regulators, competitors, suppliers and customers' (OECD 2005, p. 76). The guidelines are geared toward innovation surveys of organizations. These measures concentrate on sources knowledge and technology to be transferred; and as the results of such organizational surveys can be collected and analyzed based on metropolitan areas, they have the potential to contribute to insights on the relationship dimension of innovation.

\section{Research methodology}

To explore the relationship dimension of spatially defined innovation ecosystems, we conducted a comparative network analytic study of institutional and personal relationships among business entities, using multiple, exploratory, data-driven analyses of three metropolitan areas: (1) the Austin, Texas Metropolitan Area; (2) the Minneapolis/St. Paul (Twin Cities) Minnesota Corridor; and (3) the Greater Metropolitan Area of Paris, France. The mid-continent geographical locations of the three capital cities provided

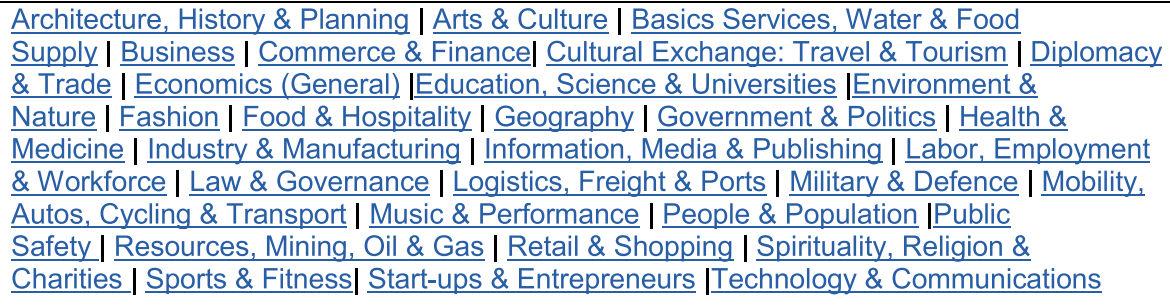

Figure 1 Screenshot of the segments of innovation indicators (2ThinkNow 2014). 
context for this comparison, and the authors' current and previous active participation in the relationships networks of these three urban areas provided sources of ground truth for sensemaking of the results of these explorations.

Our goal was to reveal insights about the innovation ecosystem of each metropolitan area to test our hypotheses that the innovation character of these areas would be reflected in the data-driven, evidence-based metrics, and visual patterns of relationship networks in each area. Generally, Austin is seen to exemplify a relatively recent but thriving entrepreneurial hub, whereas the Twin Cities Corridor has been rooted in a cohort of established family-based agribusiness and commerce enterprises, with technology enterprises and transportation emerging in recent decades. Paris has a tricentennial history as an international metropolitan area in which family-based holding companies and national-regional governmental organizations provide structure and resources for business stability and growth.

We used data from multiple data sources, both proprietary and public, about corporate and business relationships, examining companies, individuals, and financing organizations. The roles of universities are not highlighted in this paper, though they have been explored with previous studies, showing that the universities participate in business creation by connecting individuals with business intentions to each other (Rubens et al. 2011) and to organizations (Still et al. 2012). Neither is the role of government highlighted, mainly due to the limitations of the datasets used in this analysis.

Our research process was oriented to the IETF, shown in Figure 2, which emphasizes the relationship dimension of innovation as the mechanism for shared vision to be developed within and across organizations, through knowledge transfer, technology dissemination, and organizational change (Russell et al. 2011). The IETF recognizes that the co-created value as well as the progress toward desired transformations are both realized through events, their impacts over time, and through coalitions of relationships (which can be measured and tracked). Through relationships that co-create a shared vision of the future, interaction, and feedback enable people involved in change to transform the ecosystem. Changes in the actors and changes in their relationships reveal modifications in the coalitions that provide the network's structure. Over time, these shifts can be tracked, measured, and visualized to reveal and anticipate

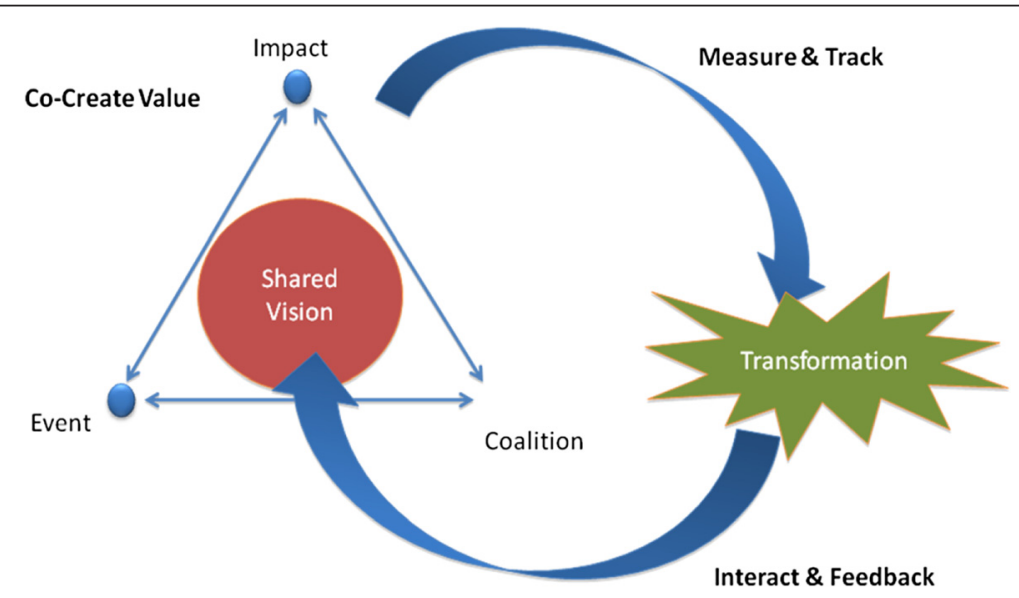

Figure 2 Innovation ecosystems transformation framework (Russell et al. 2011). Translate, measure and transform an innovation ecosystem. 
transformations (Russell et al. 2011; Still et al. 2014c). IETF has been successfully used to track, measure, and visualize snapshots of innovation regional ecosystems (Russell 1995) and transnational (Still et al. 2014a) levels.

Visualizations are integral to the IETF in that they create common ground on which shared vision can be developed. As a process research approach, IETF conceptualizes change as interrelated states in the development or growth of an organization (Van de Ven and Poole 2005). Analysis of states at single points in time provides snapshots; comparison of changes over time shows impact. Metrics revealing relational capital provide insights into the new coalitions and shared vision through which transformation can be orchestrated.

\section{Data-driven process for measuring and visualizing}

The utility of using network modeling for innovation ecosystems comes from the revelation of relationship-based structures as patterns of connections and interactions within an ecosystem (Green and Sadedin 2005). Social network analysis (SNA) studies the structure of networks of social actors (Wellman 1988). It has been used to study the sociological relationships of people and organizations (Wasserman and Faust 1994; Welser et al. 2007), as well as the nested structures of individuals, firms, and their relationships (Moody and White 2003; Halinen et al. 2012). Networks are composed of nodes and their connections, or social links (Krackhardt and Hanson 1993). Visual network analysis allows the investigators to observe the emerging structures and patterns and to share their findings to others (Freeman 2000). Network analysis can be used to reveal the flow of information, talent, and financial resources through the relationships of leadership individuals and their associated firms (Russell et al. 2011). Liu et al. (2011) have shown that understanding the structure of a network is a key factor in the controllability of both engineered and real complex networks. In this light, results of network analysis can contribute insights for ecosystem transformation.

A study of Japanese interfirm networks in regional clusters (Kajikawa et al. 2010) is one of the few examples of investigating multiscale business structures; it explored network structures with quantitative network metrics using data about supplier-user relationships. Our methodology shares basic elements of that methodology in an approach formalized

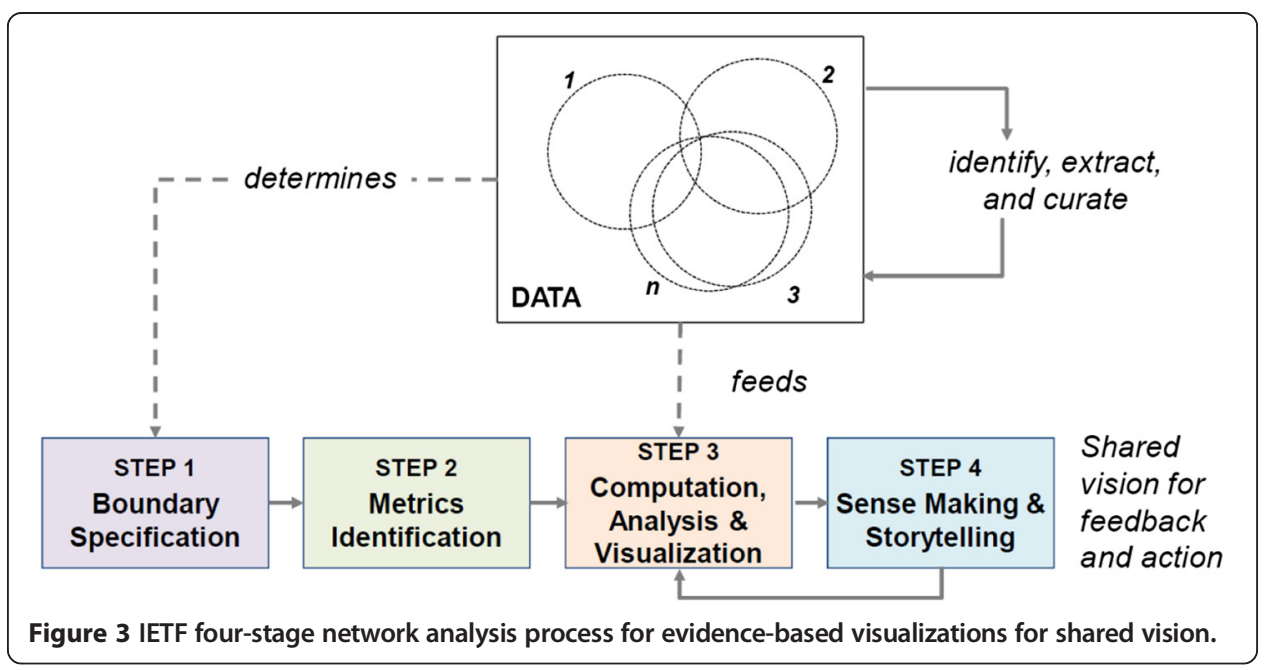


for studying innovation ecosystems. Our analytical approach is evidence-based and datadriven, using network analytics, network metrics, and their visualizations to explain the relationship dimension of innovation ecosystems. The basic approach, with $n$ sources of data, is shown in Figure 3.

The four-stage Ostinato process of developing these visualizations involves: boundary specification; metrics identification; computation, analysis, and visualization; and sensemaking and storytelling (Huhtamäki et al. 2015) and is adaptable to include a variety of analytical objectives and data sources (Basole et al. 2013a; Still et al. 2013b). The process is iterative and, therefore, can begin anywhere in the loop. The choices at each step of the four-stage network analysis process are customized for each case. Selection of the boundaries, metrics, mix of data analysis-visualizations, and sensemaking processes are based on the requirements of the insight needs of the transformation orchestration agents.

Factors associated with the changes can be further analyzed through quantitative or qualitative methods to understand opportunities for intervention in the innovation ecosystem. Visualization of the process aids in the discovery, exploration, and communication of complex business ecosystems (Basole et al. 2013a; Basole et al. 2013b; Basole 2014).

\section{Boundary specification and determining the data}

The parameters for data selection are based on the boundary specifications (Basole et al. 2015) and driven by the nature and intent of the problem, the questions being asked, and the costs involved. This process inherently includes trade-off, as setting the boundaries impacts not only the quantity of data but also might have an impact on the quality and relevance of data. It is adaptable to include a variety of data sources. When focusing on relationships, getting relational data is the key.

Boundary specification involves determining and selecting the essential parameters and data points (primitives) of the network architecture (Ahuja et al. 2012), including nodes, node types (e.g., firms, people, financial institutions, etc.), and relationship types (e.g., board participation, investment, supply chain, marketing, licensing, etc.) and specifying the desired analysis timeframe. The selection of primitives is determined by the objectives of the analysis (Huhtamäki et al. 2015).

If shortage of real-time innovation data was previously a challenge, this no longer constitutes an issue. In addition to traditional, official, and curated data, there now exists a vast sea of available data 'as the next frontier for innovation, competition and productivity' (McKinsey 2011). Through company websites, published announcements, and filings, blogposts, microblogging, and community-built information resources, as well as through open data policies increasingly being implemented (Still et al. 2012), data are openly available. These sources provide unprecedented access to new data, updated in real-time, complementing the traditional data sources of official curated data sources, which sometimes have limited availability and accessibility.

\section{Metrics identification}

Insight objectives and decision processes guide the selection of metrics for the network analysis process used for the IETF. Social network and graph theoretic metrics that can be useful for understanding the relational dynamics of an innovation ecosystem can be categorized at two levels of analysis, the whole network (ecosystem), and the node level 
(firm/individual) (Still et al. 2013a). This differentiation is important because network dynamics at each level, although related, are also distinct (Zaheer et al. 2010).

\section{Computation, analysis, and visualization}

The implementation of the computation, analysis, and visualization step is a combination of interactive computing (Goldin et al. 2010), knowledge discovery (Fayyad and Stolorz 1997), information visualization (Card et al. 1999), and visual analytics (Wright 1997; Heer and Shneiderman 2012). Raw data that is harvested across various sources, online, and proprietary, as required by the case context, is refined and curated to create a coherent and consistent dataset that provides a solid base for the analysis. From this data, network representations of the underlying structure of an ecosystem are created (Huhtamäki et al. 2015). Both actor (node) and network (ecosystem) level metrics can be calculated, and the data is transformed to support the analysis and facilitate sensemaking and storytelling through visualizations of the networks structure.

\section{Sensemaking and storytelling}

Sensemaking is an important aspect of insight and development. It has been used in many domains including organizational research, educational research, and decision science (Weick 1995); yet there is no universal definition for sensemaking. Klein et al. (Klein et al. 2006) offer two forms of definitions: the simple one is 'making sense of things'; the more comprehensive one is 'a motivated, continuous effort to understand connections which can be among people placing events in order to anticipate that trajectories and act effectively'. Using the data/frame theory (Klein et al. 2006), the sensemaking process takes place within a frame - here the IETF. The Frame manages our attention as we define, connect, and filter the data. Visualizations facilitate this process. By tracking anomalies, detecting inconsistencies, judging plausibility, and gauging data quality, we Question the Frame. If we disagree with the frame, we go back to the data and reframe. If we agree with the frame, we preserve it and elaborate on it by adding and filling slots, seeking inferring data, discovering new data and relationships, and discarding data. Through iteration and discussion, stakeholders may detect a pattern and match and/or adjust their frame - or mental model, their shared vision. Together, this forms a complete sensemaking loop.

While information visualization includes data transformation, representation, and interaction, it is ultimately about harnessing human visual perception capabilities to help identify trends, patterns, and outliers. Sensemaking has its roots in cognitive psychology, and many different models have been developed (North 2006). The consensus across these models is that sensemaking procedures are cyclic and interactive, involving both discovery and creation. During the generation loop, an individual searches for representations. In the data coverage loop, these representations are instantiated. Based in these insights, the representation may be shifted to begin the process again.

The sensemaking and storytelling step of the IETF process is closely linked to the insight objectives (Konno et al. 2014), and the iteration of the analytical process is the key in identifying programmatic and messaging opportunities to activate action plans (Card et al. 1999). Visualizations and their dissemination through storytelling also serve to amplify social capital through its cognitive dimension (Nahapiet and Ghoshal 1998). The true purpose of visualization is more than pretty pictures and does not eliminate the need for 
human insight and foresight (McAfee and Brynjolfsson 2012). Möller and Rajala (2007) have recognized that network orchestrators must engage in sensemaking for external audiences who have little or no prior understanding of a proposed initiative or its 'rightness'.

\section{Comparative analysis of three metropolitan areas}

Our comparative network analytic study of complex systems used data-driven network metrics and their visualizations to explain the relationship dimension of three metropolitan innovation ecosystems.

Table 1 Metropolitan area indicators for the innovation ecosystem cases

\begin{tabular}{|c|c|c|c|c|}
\hline Source & Indicator & $\begin{array}{c}\text { Austin } \\
\text { Metropolitan } \\
\text { Area }\end{array}$ & $\begin{array}{l}\text { Twin Cities } \\
\text { Corridor }\end{array}$ & $\begin{array}{c}\text { Greater } \\
\text { Metropolitan } \\
\text { Paris }\end{array}$ \\
\hline \multirow[t]{9}{*}{ OECD metro database ${ }^{a}$} & Population in cities (2012) & 1.8 million & 3.4 million & 11.8 million \\
\hline & Total land area (2012) & $11,084 \mathrm{~km}^{2}$ & $16,402 \mathrm{~km}^{2}$ & $12,089 \mathrm{~km}^{2}$ \\
\hline & $\begin{array}{l}\text { Concentration of pop in the } \\
\text { core (2012) }\end{array}$ & $67,98 \%$ & $49,78 \%$ & $79.27 \%$ \\
\hline & Labor force (2012) & 0.9 million & 1.8 million & 5.7 million \\
\hline & $\begin{array}{l}\text { Unemployment annual } \\
\text { average growth rate (2012) }\end{array}$ & $6.999 \%$ & $5.716 \%$ & $0.289 \%$ \\
\hline & GDP (2010) & 78 billion US\$ & 148 billion US\$ & 579 billion US\$ \\
\hline & GDP per capita (2010) & 45,405 US\$ & 45,342 US\$ & 49,498 US\$ \\
\hline & $\begin{array}{l}\text { PCT patent applications per } \\
10,000 \text { inhabitants }(2008)\end{array}$ & 2.68 & 5.21 & 2.14 \\
\hline & $\begin{array}{l}\text { PCT patent application } \\
\text { annual growth (2008) }\end{array}$ & $-1.41 \%$ & $2.26 \%$ & $4.52 \%$ \\
\hline \multirow{3}{*}{$\begin{array}{l}\text { Brookings Institute, } \\
\text { The Metro Monitor }^{b}\end{array}$} & Combined performance & $1 \mathrm{st}$ & 30th & - \\
\hline & $\begin{array}{l}2014 \text { of } 100 \text { Us } \\
\text { Metropolitan areas }\end{array}$ & Recession: 7th & Recession: 53rd & \\
\hline & & Recovery: 2nd & Recovery: 39th & \\
\hline \multirow[t]{3}{*}{$\begin{array}{l}\text { Brookings Institute, } \\
\text { The Global Metro } \\
\text { Monitor }{ }^{c}\end{array}$} & $\begin{array}{l}\text { Economic growth data } \\
\text { (real GDP per capita and } \\
\text { employment change) for } \\
\text { the largest } 300 \text { metropolitan } \\
\text { economies worldwide, } \\
2011 \text { to } 2012\end{array}$ & $61 \mathrm{st}$ & 209th & 262nd \\
\hline & GDP (2012) & 91.7 billion US\$ & 192.0 billion US\$ & 669.2 billion US\$ \\
\hline & GDP per capita (2012) & 49,844 US\$ & 57,348 US\$ & 53,881 US\$ \\
\hline \multirow[t]{4}{*}{$\begin{array}{l}\text { Brookings Institute, } \\
\text { The } 20 \text { most innovative } \\
\text { cities in the US }\end{array}$} & $\begin{array}{l}\text { Patenting and innovation } \\
\text { in Metropolitan America } \\
\text { (2013) }\end{array}$ & Number 9 & Number 20 & - \\
\hline & Patents per million residents & 1,503 & 945 & \\
\hline & $\begin{array}{c}\text { Average number of } \\
\text { patents per year }\end{array}$ & 2,497 & 3,068 & \\
\hline & Top industry & $\begin{array}{l}\text { Computer } \\
\text { hardware/ } \\
\text { peripherals }\end{array}$ & $\begin{array}{l}\text { Surgery } \\
\text { and medical } \\
\text { instruments }\end{array}$ & \\
\hline $\begin{array}{l}\text { Innovation cities } \\
\text { index } \text { global }^{\mathrm{e}}\end{array}$ & $\begin{array}{l}\text { Global ranking with } 445 \\
\text { benchmark cities, analyst } \\
\text { ranked this year (2014) }\end{array}$ & Number 44 & Number 57 & Number 5 \\
\hline
\end{tabular}

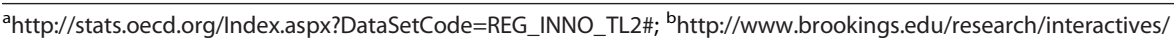
metromonitor\#/M12420; Chttp://www.brookings.edu/research/interactives/metromonitor\#/M33460;

${ }^{d}$ http://www.brookings.edu/research/interactives/2013/metropatenting; ${ }^{e}$ http://www.innovation-cities.com/innovationcities-index-2014-global/8889. 


\section{Boundary specification and context of three metropolitan areas}

In this exploration, we concentrated on the three metropolitan areas of: Austin, Texas ${ }^{\mathrm{b}}$, the Twin Cities of Minnesota ${ }^{c}$, and Metropolitan Paris ${ }^{\mathrm{d}}$. As shown in Table 1, the profiles of these three mid-continent capitals were expected to be different, justifying their selection for the purposes of this paper. The selection was further supported on the basis of knowledge available through previous ecosystem studies of Austin (Russell et al. 2013a), the Twin Cities Corridor (Russell et al. 2013c), and Metropolitan Paris (Russell et al. 2013b).

\section{Determining the data}

To reveal insights about the overall innovation ecosystem of each metropolitan area, multiple sources of data about relationships were used to create three datasets, as shown in Table 2. We used curated data for Deals and Alliance Relationships (DAR) among companies - a single-mode dataset - to understand the context of innovation created by established businesses. We used curated multimodal datasets - companies, their key individuals, and financing organizations - built from openly available online sources for Executive and Finance Relationships (EFR) and Startup and Angel Relationships (SAR). All data sources were cumulative over the same time periods. From each of the three data sets (DAR, ERF, and SAR), we selected companies with headquarters or branch offices having mailing addresses in the metropolitan areas of: Austin, Texas; the Twin Cities Corridor; and Metropolitan Paris. The spatial identification of each area included the suburban city names associated with respective identification of that metropolitan area. For purposes of comparability, neither educational nor government agencies were included; the emphasis in this analysis is on business relationships.

Table 2 Comparison of data sources and datasets

\begin{tabular}{|c|c|c|c|}
\hline & $\begin{array}{l}\text { DAR } \\
\text { Deals and Alliances Relationships, }\end{array}$ & $\begin{array}{l}\text { EFR } \\
\text { Executive and Finance } \\
\text { Relationships }\end{array}$ & $\begin{array}{l}\text { SAR } \\
\text { Startup and Angel } \\
\text { Relationships }\end{array}$ \\
\hline Source & $\begin{array}{c}\text { Proprietary (Thomson Reuters Financial) } \\
\text { based on US SEC Data }\end{array}$ & \multicolumn{2}{|c|}{$\begin{array}{l}\text { Innovation Ecosystems (IEN) dataset (Rubens et al. } \\
\text { 2010), a socially constructed data source maintained } \\
\text { for research purposes (based on social media, news, } \\
\text { and press releases) }\end{array}$} \\
\hline Type of data & $\begin{array}{l}\text { Alliance data (strategic, R\&D, marketing, } \\
\text { manufacturing, licensing, and supply) and } \\
\text { status (active, terminated, pending) of } \\
\text { public and private firms (37 SIC Codes, } \\
\text { 4-digit) }\end{array}$ & \multicolumn{2}{|c|}{$\begin{array}{c}\text { Relationship data of public and private firms, } \\
\text { founders and key executives, angels and financial } \\
\text { organizations, educational institutions, funding } \\
\text { rounds, acquisitions, investments by individuals } \\
\text { and companies }\end{array}$} \\
\hline $\begin{array}{l}\text { Types of } \\
\text { relationships }\end{array}$ & Corporation to corporation & \multicolumn{2}{|c|}{$\begin{array}{l}\text { Individuals to companies, financing by individuals, } \\
\text { companies, and VCs to companies, individuals to } \\
\text { educational institutions }\end{array}$} \\
\hline Years covered & \multirow[t]{2}{*}{ 1/1/1990 to 2014 , cumulative } & $\begin{array}{l}\text { 1/1/1994 to } 2014 \\
\text { cumulative }\end{array}$ & $\begin{array}{l}2010 \text { to } 2014, \\
\text { cumulative }\end{array}$ \\
\hline Data size & & $\begin{array}{l}\text { More than } 200,000 \\
\text { companies and more than } \\
200,000 \text { key individuals }\end{array}$ & $\begin{array}{l}\text { More than } 50,000 \\
\text { companies and almost } \\
150,000 \text { individuals. }\end{array}$ \\
\hline Comment & $\begin{array}{l}\text { One of the most prominent, } \\
\text { comprehensive, and accurate commercial } \\
\text { databases used in the study of global } \\
\text { interfirm relationships across multiple } \\
\text { sectors (Schilling 2009) }\end{array}$ & \multicolumn{2}{|c|}{$\begin{array}{c}\text { Collection of socially constructed data about } \\
\text { technology-oriented companies in the information } \\
\text { communication technology fields and the service } \\
\text { companies (legal, accounting, advertising) that } \\
\text { support them }\end{array}$} \\
\hline
\end{tabular}


Metrics selection, computation, analysis, and visualization

We focused on the relational structure of three spatially defined areas, describing the relationship networks of business ecosystems at three layers of the ecosystem - enterprise, growth, and startup - creating a multiscopic view at the macro-, meso-, and micro-levels of the innovation ecosystem (Kajikawa et al. 2010; Still et al. 2012; Basole et al. 2015). The selection of metrics to describe the relationship dimension of the three metropolitan innovation ecosystems was guided by the spatial emphasis of this journal issue and the data available.

Snapshot metrics of deals and alliances among enterprises use several metrics to reveal relational capital for each metropolitan area. These metrics describe the business context in which new companies are growing. Snapshot metrics of the ecosystemic variables recommended by Still et al. (2014a) and, as shown in Table 3, were used to reveal the context of the established business environment (DAR) and the creation of new innovation networks (EFR and SAR) in each metropolitan area. The links between nodes reflect relationships, which Jackson (2008) refers to as equilibrium states reflecting choices based on the availability, as well as the cost and benefits, of relationship formation. For all levels of the regional networks, strategic intent in link formation is assumed. In this context, we have interpreted network metrics as indicators of the relational capital of innovation ecosystems: Profile, Engagement, Relational Potential, Vitality, Linking Factor, and Embeddedness.

- The quantities and proportions of various types of actors (nodes) and their ties (edges) provide a Profile of strategic relationships. We computed the Ratio of Edge-to-node to indicate the Profile of the relational capital at each level (Russell et al. 2011).

- In the single-mode networks at the enterprise level, we used Average Degree value to indicate the Relationship Potential of the ecosystem. By Relational Potential, we refer to the number of connections available - that could be established. In a fashion similar to scale-free networks (Barabási and Bonabeau 2003), the probability of like entities becoming connected is proportional to the Average Degree (Newman 2002).

Table 3 Network metrics for ecosystem relational capital indicators

\begin{tabular}{|c|c|c|}
\hline Relational capital indicator & Description & Network metric \\
\hline \multirow[t]{3}{*}{ Profile } & The size and composition of the ecosystem & Number of nodes \\
\hline & & Numbers of edges \\
\hline & & Types of actors \\
\hline Engagement & $\begin{array}{l}\text { Number of connections between nodes } \\
\text { in the ecosystem }\end{array}$ & Ratio of edge to node \\
\hline Relationship potential & $\begin{array}{l}\text { Average number of available connections } \\
\text { per entity }\end{array}$ & Average degree \\
\hline Vitality & $\begin{array}{l}\text { The actual interconnectedness in the } \\
\text { ecosystem relative to the potential }\end{array}$ & Density \\
\hline Linking Factor & $\begin{array}{l}\text { Showing the availability of bridging } \\
\text { relationships across the ecosystem }\end{array}$ & Average betweenness centrality \\
\hline Embeddedness & $\begin{array}{c}\text { The ecosystem's ability to change over } \\
\text { time based on the connections among } \\
\text { individual entities }\end{array}$ & $\begin{array}{l}\text { Main component - size } \\
\text { and proportion }\end{array}$ \\
\hline
\end{tabular}


- We used network Density (the actual edges divided by the potential edges) as a measure of the Vitality of the ecosystem, its health, and liveliness - the extent to which transactions in that city may occur.

- As an indicator of the Linking Factor, we use Average Betweenness Centrality to show the availability of bridging relationships across the ecosystem (Still et al. 2014a).

- As an indicator of Embeddedness, a state of cohesion in which a group's members possess bonds linking them to one another and to the group as a whole (Cartwright 1968), we computed the size of the Main Component and the proportion of total nodes in the Main Component. We used Embeddedness as an indicator of shared vision (Russell et al. 2011). Embeddedness reflects the connections among individual entities (Licht 2010), as an indicator of how entities within that ecosystemic level can reach each other, directly or indirectly, from the 'friends of friends' perspective (Burt 1992; Coleman 1990).

To present the data as a network and its metrics in a visual form, we developed a set of tailored batch-processing tools in Python. These tools compile the source data according to the boundary specification, create the network, and calculate metrics. To explore and visualize the networks, we used Gephi, an interactive network analysis platform that implements a core set of key functionalities for visual network analytics (Bastian et al. 2009). These network layouts were created using a force-driven algorithm in which nodes repel each other and edges pull the connected nodes together (Noack 2009), revealing the spatial structure of relationships. Color coding was added to differentiate node type: red shows companies; green shows finance organizations; and blue shows key individuals (founders, C-suite, board members.) In a graph theoretical perspective, force-driven layout reveals the macro-level structure of the network including the key clusters, the key brokers in the network, as well as possible structural holes (Burt 1992).

\section{Sensemaking and storytelling}

The sensemaking step completes the cycle, using spatial descriptions, regional business history, and collateral metrics of the three metropolitan areas to provide context for the relational capital revealed in the networks of the three innovation ecosystems. In this paper, storytelling is deployed to provide context for interpreting the quantitative results of the analysis across relational indicators at three levels of the three ecosystems.

\section{Findings}

The findings are expressed in a snapshot approach in order to gain insights into the cumulative structure of their innovation ecosystems. Quantitative indicators reveal insights about the particular profiles and structures; however, when presented with the network visualizations (Figures 4, 5, and 6), the structures become explicit and actionable. Relational indicators are presented for the enterprise level of the three metropolitan ecosystems, followed by the growth and the startup levels. 


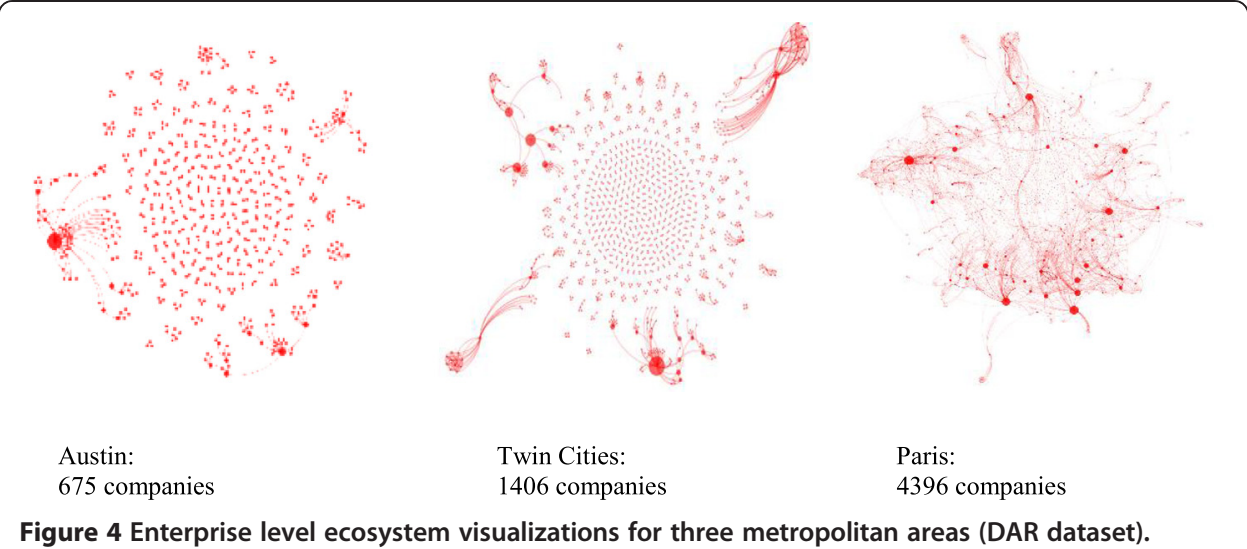

The enterprise level: deals and alliances (DAR)

At the enterprise level, deals and alliances with local firms reflect each network's character, its size, density, agility, and closure or openness (Moody and White 2003; Kajikawa et al. 2010) based on local relationships ${ }^{\mathrm{e}}$ in the ecosystem.

\section{Austin's enterprise level: deals and alliance relationships}

Our sample of enterprises reporting deals and alliances during the 1990 to 2013 period revealed 497 deal or alliance transactions among 675 Austin-based companies during the 13-year period of this data. Several discrete components can be seen in Figure 4, and the main component in this level includes $11 \%$ of the companies in Austin's enterprise ecosystem, as shown in Table 4. Although the size of the components seen in Figure 4 differs significantly, two show a pattern of second-order relationships, that is, the companies with which they transacted also made deals and alliances with other companies.

\section{Twin cities deals and alliance relationships}

The enterprise level of deals and alliances in the Twin Cities Corridor, as shown in Figure 4, consists of 1,406 companies connected by 1,126 transactions, with an edgeto-node ratio of $87 \%$. Four discrete components are observed in this level, and they

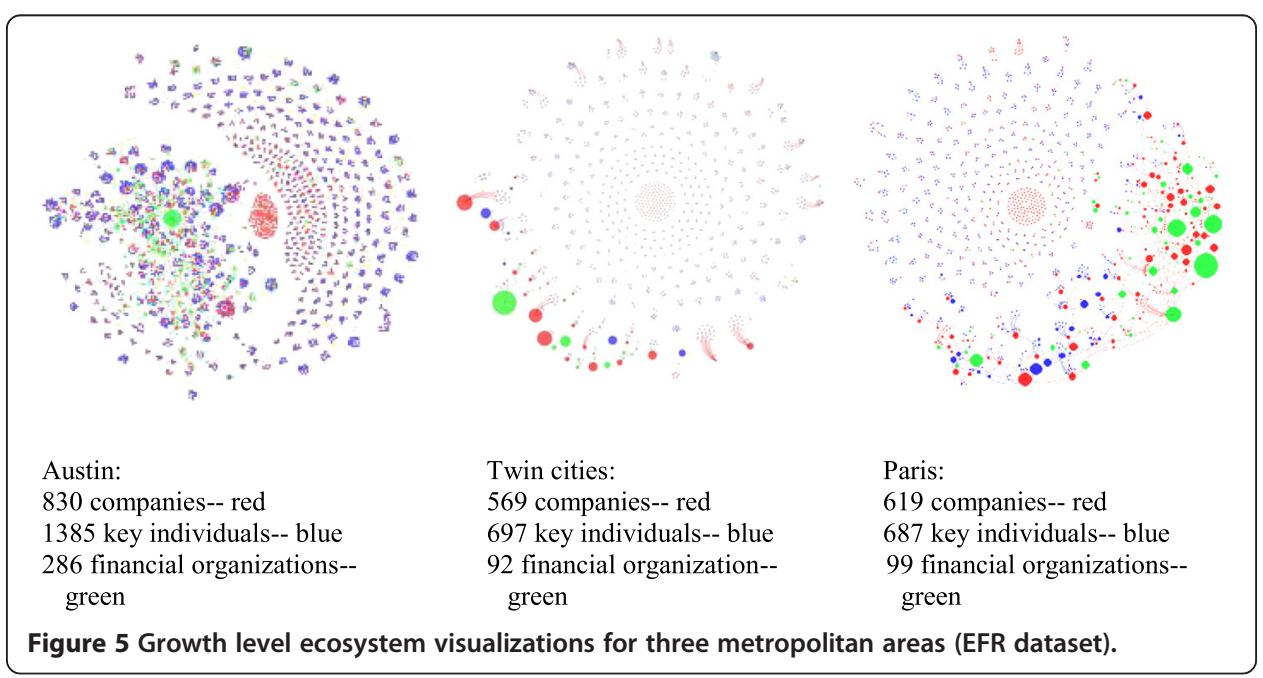




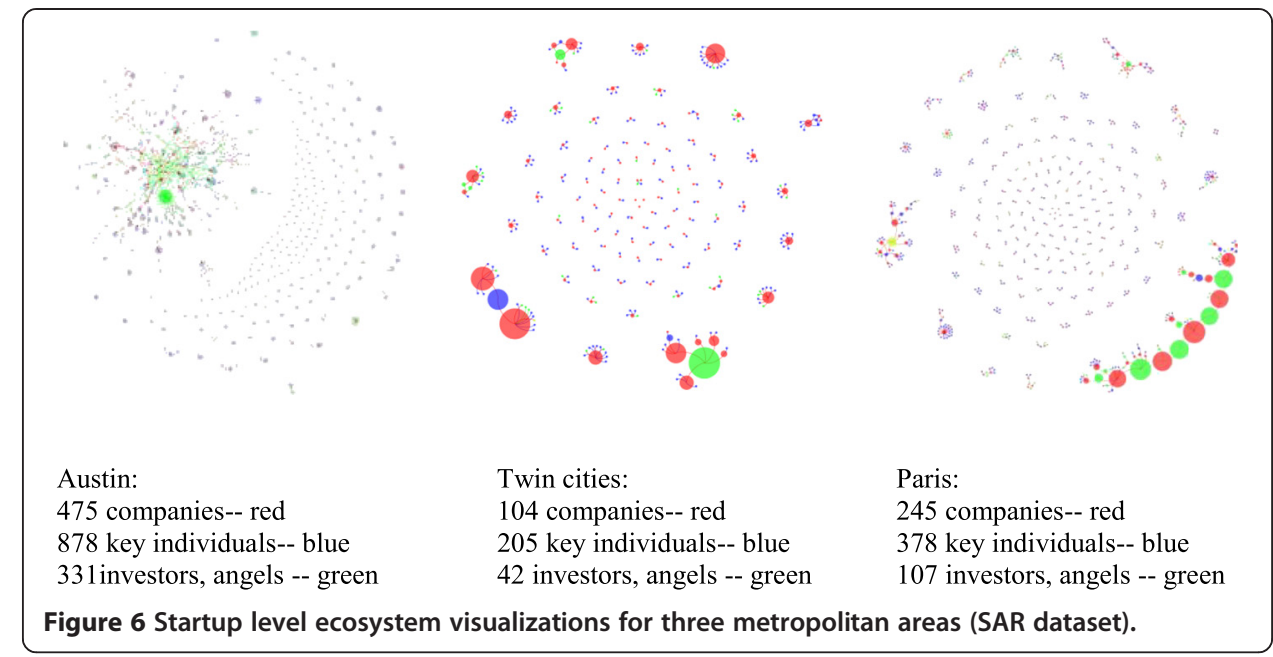

are not interconnected to each other through Twin Cities companies. The main component contains 86 nodes, reflecting only $6 \%$ of the Twin City enterprises linked to this largest component.

\section{Parisian deals and alliance relationships}

The enterprise level of Greater Paris includes 4,396 businesses in the DAR dataset; they are connected through 6,077 deal and alliance transactions, showing high relational capital in the edge-to-node ratio of $138 \%$. As shown in Table 4, the main component includes 2,699 nodes (61\%) of the nodes in the level. Clockwise in Figure 4, the interconnected components reflect the chemical, medical, software, mobile, energy, telecommunications, technology, banking, and travel.

The growth level: executive and financing relationships

At the growth level, companies have access to knowledge, financial resources, and labor through relationships with key executives and financial organizations, as well as through business relationships with larger enterprises.

Table 4 Enterprise level ecosystem relationship indicators for three metropolitan areas (DAR dataset)

\begin{tabular}{lcccc}
\hline Relational indicators & Network metric & Austin & Twin cities & Paris \\
\hline Profile & Number of nodes & 675 & 1406 & 4396 \\
& Number of edges & 497 & 1126 & 6077 \\
Engagement & Ratio of edge to node & 0.74 & 0.87 & 1.38 \\
Relational potential & Average degree & 1.47 & 1.74 & 2.77 \\
Vitality & Density & 0.0022 & 0.0012 & 0.0011 \\
Linking factor & Average betweenness centrality & 0.0001 & 0.0000 & 0.0004 \\
Embeddedness & Main component & & & \\
& Number of nodes & 72 & 86 & 2699 \\
& Percent of nodes & 11 & 6 & 61 \\
\hline
\end{tabular}


Table 5 Growth level ecosystem relationship indicators for three metropolitan areas (EFR dataset)

\begin{tabular}{lcccc}
\hline Relational indicators & Network metric & Austin & Twin cities & Paris \\
\hline Profile & Number of nodes & 2,501 & 1,358 & 1,405 \\
& Number of edges & 2,193 & 978 & 1,102 \\
Engagement & Ratio of edge to node & 0.88 & 0.72 & 0.78 \\
Relational potential & Company avg degree & 2.89 & 1.94 & 1.88 \\
& Finance org avg degree & 1.76 & 1.35 & 3.12 \\
& Individual avg degree & 1.03 & 1.05 & 1.07 \\
Vitality & Density & 0.0007 & 0.0011 & 0.0011 \\
Linking factor & Average betweenness centrality & 0.0022 & 0.0018 & 0.0002 \\
Embeddedness & Main component & 1,132 & 190 & 428 \\
& Number of nodes & 45 & 14 & 30 \\
& Percent of nodes & & & \\
\hline
\end{tabular}

Austin's growth level: executives and financing relationships

Growth companies with primary or branch offices in the Austin Metropolitan Area ecosystem of finance and executive relationships include 830 companies (red nodes). As shown in Figure 5, these companies are connected by 2,193 relationships (edges), which include 1,385 executive-level individuals (blue nodes) and 286 financing organizations (green nodes) in the Austin growth level. The high ratio of key individuals and financial organizations to Austin companies can be seen in Table 5. The average degree value of Austin growth companies is 2.89 , and the financial organizations in the growth level show an average degree value of 1.76 . The average betweenness centrality for the Austin growth level is 0.0022 .

\section{Twin cities executives and financing relationships}

The growth companies in the Twin Cities Region (Figure 5) consist of 1,358 nodes and 978 edges, and its ecosystem level has an edge-to-node ratio of $72 \%$. Ninety-two (92) financial partners, 697 key individuals, and 569 companies are present in this level, and the main component consists of 190 nodes, $14 \%$ of the nodes in the level (Table 5). The average betweenness centrality for the Twin Cities growth level is 0.0018 .

\section{Parisian executives and financing relationships}

The ecosystem level of Parisian growth companies is visualized in Figure 5 and includes 1,102 edges and 1,405 nodes, of which 619 are companies, 687 are key individuals, and 99 are financing organizations. The average degree value of companies, financing organizations, and individuals are 1.88, 3.12, and 1.07, respectively. Table 5 shows that the ratio of edge to node in the Parisian growth level is $78 \%$, with a density value of 0.001 , and that companies in this growth level have an average degree value of 1.88 . The main component consists of 428 nodes, $30 \%$ of the level; the average betweenness centrality is 0.0002 .

\section{The startup level: startup and angel relationships}

The startup level reflects the nursery of innovation in each of the regional metropolitan areas. The survival and growth of new companies require resources from relationships with key executives, investors, and angels. 


\section{Austin startup and angel relationships}

Our data reveal that during the period of 1995 to 2014, 475 startup companies were launched in the Austin Metropolitan Service Area. Eight hundred seventy-eight (878) key individuals and 331 investors and angels have been associated with Austin startup companies, and the relationships of these individuals to the startup companies indicate an edge-to-node ratio of $98 \%$ and a density value of 0.0012 . As shown in Figure 6, the largest component includes 825 nodes (49\%) and has an average degree value of 3.46 for Austin's startup companies. The average betweenness centrality for Austin's startup level is 0.0017.

\section{Twin cities startup and angels relationships}

In Figure 6, we see that the startup level of the Twin Cities consists of 351 nodes, of which 104 are companies, 205 are key individuals, and 42 are investors and angels. The density value of this level is 0.0044 ; the average degree value of companies in this level is 2.57. The ratio of nodes to edges in the Twin Cities startup level is 67\%, with 18 nodes (5\%) in the largest component (Table 6). The average betweenness centrality of companies in the Twin Cities startup level is 0.00001 .

\section{Parisian startup and angels relationships}

Figure 6 shows the Parisian startup level and reveals 576 edges and 730 nodes, of which 245 are companies, 378 are key individuals, and 107 investors and angels. The ratio of edge to node in the Parisian startup level, as shown in Table 6, is 79\%. The average degree value of companies at this level of the ecosystem is 2.35. The density value is 0.00216 , with an average betweenness centrality of 0.0001 . The main component of this level includes 82 nodes (11\%) of the ecosystem.

\section{Discussion}

In this paper, we explored how relationships in innovation ecosystems, spatially defined by metropolitan areas, can be analyzed and visualized to characterize multiscopic innovation ecosystems at the enterprise, growth, and startup levels. Data-driven visualizations and metrics provided a description of 'an ecosystem' in which companies, individuals, and financing organizations co-innovate to solve economic challenges (Smith and Leydesdorff 2011). As neither ranges nor benchmarks for relational indicators have been established, we discuss our findings in a relative sense, comparing metrics within

Table 6 Startup level ecosystem relationship indicators for three metropolitan areas (SAR dataset)

\begin{tabular}{|c|c|c|c|c|}
\hline Relational indicators & Network metric & Austin & Twin cities & Paris \\
\hline \multirow[t]{2}{*}{ Profile } & Number of nodes & 1684 & 351 & 730 \\
\hline & Number of edges & 1642 & 267 & 576 \\
\hline Engagement & Ratio of edge to node & 0.98 & 0.76 & 0.79 \\
\hline \multirow[t]{2}{*}{ Relational potential } & Company avg degree & 3.46 & 2.57 & 2.35 \\
\hline & Individual avg degree & 2.56 & 1.00 & 1.17 \\
\hline Vitality & Density & 0.0012 & 0.0044 & 0.0022 \\
\hline Linking factor & Average betweenness centrality & 0.0017 & 0.0000 & 0.0001 \\
\hline \multirow[t]{3}{*}{ Embeddedness } & Main component & 825 & 18 & 82 \\
\hline & Number of nodes & 49 & 5 & 11 \\
\hline & Percent of nodes & & & \\
\hline
\end{tabular}


Table 7 Relative relational capital indicators of ecosystem levels in three metropolitan areas

\begin{tabular}{lccccc}
\hline Indicator & Engagement & Relational potential & Vitality & Linking factor & Embeddedness \\
\hline $\begin{array}{c}\text { Austin } \\
\text { Enterprise }\end{array}$ & Low & Moderate & Moderate & Low & Low \\
Growth & Moderate & High & Low & High & Moderate \\
Startup & High & High & Moderate & High & Moderate \\
Twin cities & & & & \\
Enterprise & Low & High & Moderate & Low & Low \\
Growth & Low & Moderate & Moderate & High & Low \\
Startup & Moderate & Moderate & High & Low & Low \\
Paris & & & & & High \\
Enterprise & Moderate & High & Low & Low & Moderate \\
Growth & Moderate & Moderate & Moderate & Low & Low \\
Startup & Moderate & Moderate & Moderate & Low & \\
\hline
\end{tabular}

datasets across three metropolitan areas. Relational indicators reveal integrity of the indicators within each of the three metropolitan areas and show interesting similarities and differences across the three business ecosystems, as shown in Table 7.

\section{Greater Austin, an entrepreneurial region}

The Greater Austin business innovation ecosystem shows relatively high relational potential and linking factor at the growth and startup levels and relatively high engagement at the startup level. The vitality of Austin's growth level is concentrated in the financial organizations, companies, and key individuals that are already part of the main component of networked innovation; other entities in the growth level are less connected to local resources. The relatively low density of the Austin growth level indicates a general pattern of single relationships for many of the nodes, in contrast to the very large main component. Entities connected to this main component are likely to have access to the flow of insights, talent, and financial resources in the growth level of Austin's ecosystem, while those not included in it may be impoverished for such resources. Austin is known for its tolerance to alternative lifestyles, and some unconnected companies may be lifestyle businesses. Risk is inherent in innovation, and the presence of financial institutions at both the growth and startup levels may indicate a local willingness to accept the risk of failure that is inherent in creating new businesses. It would be reasonable to expect companies in Austin's growth level to increasingly reach outside the Austin Metropolitan area for additional relational capital to fuel their transition to the enterprise level.

The enterprise level of Greater Austin's innovation ecosystem shows relatively modest local relational capital, as seen in the relatively low linking factor of Austin enterprises. Austin's deals and alliances reveal little interdependence between Austin-based corporations and the enterprises with central roles in the two larger components. The relatively low social cohesion and vitality of Austin's enterprises may indicate their reliance on relationships outside the Greater Austin area for resources. The smaller size of the main component in the enterprise level may indicate less dependence on local relationships, in the context of global deals and alliances. 


\section{Twin cities corridor, a low-risk stable region}

The relational capital of the Twin Cities is distributed across the various levels of the ecosystem. The enterprise level has the largest number of entities and has the highest relational capital - as shown by the ratio of edge to node, although its main component is relatively small, perhaps due to a reliance on non-local deals and alliances rather than local ones. The growth level exhibits the greatest embeddedness and exists in the context of a modest relational capital, shown by the edge-to-node ratio. Resources of the local financial organizations create connections across a number of growth companies, but the availability of enterprise support (corporate investments or deals) is a key aspect of the Twin Cities ecosystem. Although small, the startup level of the Twin Cities business ecosystem has relatively high degree value and density. Like the growth level, the companies in the startup level are dependent on relationships with larger local companies to assure survival and fuel growth. Synergies across the few small clusters to help them acquire investments and sales are a yet unrealized potential.

Relational assets for innovation can be found in the relatively high relational potential of its enterprise level, in the relatively high vitality or its startup level, and in the relatively high linking factor of its growth level. Twin Cities startups may find it easier to grow by establishing supplier relationships with local enterprises than through investment from financial organizations. Three key entities dominate the relationships at the growth level. Few Twin Cities financial organizations have multiple local investments, and local co-investments are also infrequent. Embeddedness due to deals and alliances among Twin Cities enterprises is low ${ }^{\mathrm{g}}$.

\section{Metropolitan Paris, entrepreneurial energy within a legacy area}

The relational capital for innovation in Metropolitan Paris shows yet another profile. The strength of the Paris business ecosystem resides in the relational capital and social cohesion of the large and well-connected enterprise level of the ecosystem. All businesses have at least one connection, and the dominance of the very large main component, against the low density value, indicates a scale-free profile, in which preferential advantage among entities in the main network is highly likely. At the enterprise level, the analysis shows relatively high embeddedness and relational potential; local strength is global for Parisian enterprises. This may indicate a scale-free scenario, reflecting an environment of 'rich get richer' through preferential attachment (Barabási and Bonabeau 2003). The Parisian innovation ecosystem is dominated by its enterprises.

The relational potential of Parisian companies at the growth and startup levels is modest, as is their vitality. The high degree value of the startup level of the Parisian ecosystem and the relatively high density value indicate vitality in this level, even in the absence of strong social cohesion that might be exhibited with greater connectivity across the small clusters in the startup level. A cohort of financial organizations invests in multiple Parisian companies and co-invests with other Parisian financial organizations. The companies' degree value is in contrast to the density level and the average betweenness centrality, perhaps indicating a chasm in the relational capital of the Paris enterprise ecosystem - a separation between the independent businesses and those that are part of the establishment.

\section{Insights for network orchestration}

Across the three ecosystems, indicators of relational capital provide important insights into the complexity of the business strand of the Triple Helix. Within this strand, the 
relationship profiles and dynamics of the ecosystems suggest insights for network orchestration.

Up to the mid-1980s, the activities of the flagship campus of The University of Texas and Austin's capitol city dominated the identity and economy of the Austin Metropolitan Area. With the infusion of highly educated technical professionals who came to Austin to establish the USA's first for-profit R\&D consortium (Microelectronics and Computer Technology Corporation, MCC) and the relocation of 3 M's research operations, the Austin ecosystem changed (Browning et al. 1995; Gibson \& Rogers 1994). With their migration, those high-tech argonauts (Saxenian 2007) exhibited an ability to change and innovate; they brought their networks as well as their knowledge. Their continuing relationships with enterprises and other entities in their original cities may hold untapped relational capital for Austin. Interventions in the Greater Austin ecosystem could be directed to helping companies in the dynamic growth and startup levels achieve scale through relationships with non-local financial organizations and through deals and alliances with non-local companies. Access to these non-local relationships could be facilitated through relationships with local enterprises.

The evolution of the innovation ecosystem in the Twin Cities Corridor has taken place in the context of a local economy that dominates its regional context. The economic basis of the Twin Cities evolved from milling to mining to mainframes. During the mid-twentieth century, national R\&D programs fueled the growth of technology companies and gave rise to a cohort of information technology companies focused on computers. The information computer technology (ICT) sector underwent a serious decline during the mid-80s when Minnesota enacted stiff environmental regulations that controlled the toxic chemicals used in semiconductor manufacturing. The surviving elements of the Twin Cities' ICT ecosystem were those based on medical technologies, most components of which could be procured from non-Minnesota firms and assembled into sophisticated finished products in Minnesota, building core competencies in outsourcing and distribution. Interventions to energize innovation that contributes to the Twin Cities' Corridor's economy could leverage the shared vision among key individuals who survived this transition and have already built an embedded culture of philanthropy and social services. Their primary and secondary business connections create the potential of one company's relationships to serve as resources for another company. Secondary connections within the ecosystem add to local relational capital. The relational capital of established enterprises could be leveraged to build a shared vision of opportunities for local startups, risk-taking for innovation, and of co-investing by financial organizations and angels.

As in the Twin Cities Corridor, the historical antecedents of relationships observed in the Paris Metropolitan Area ${ }^{\mathrm{h}}$ ecosystem may have produced resistance to disruptive forces (Gross and Martin 1952) aligned judgments (Lott and Lott 1965), and strengthened self-regulating processes of rewards and punishments within the ecosystem. Power inequity exists between the relational capital of highly connected nodes in the enterprise level and those of the emerging growth and startup levels. In Metropolitan Paris, interventions could focus on building local collaborations among enterprises, growth companies, and startups, as well as increasing the relationship capital among angels and financial organizations to build a shared understanding of perceived social rewards for taking innovation risks. Interventions at the enterprise level could catalyze 
advising, investing, and contracting relationships with emerging companies and could also enhance the resilience of enterprises to evolve their business models in the context of global competition. New initiatives, such as those of CapDigital and similar change agents, increase the relational capital of growth and startup companies by facilitating the collaboration of small companies and enterprises on national and European projects. These may expand local resources for Parisian startups and help Parisian growth companies step up to enterprise alliances.

The innovation ecosystems in all three metropolitan areas illustrate the inherent tension between embeddedness and agility. Entities in a relationship network can share knowledge, economize costs and pool resources, and obtain access to markets and technologies (Burt 1992; Eisenhardt and Schoonhoven 1996; Powell et al. 1996; Uzzi 1996; Owen-Smith and Powell 2009). Learning ability and absorptive capacity are enhanced through relationships (Cohen and Levinthal 1990), as knowledge is processed and moved through relationships (Podolny and Page 1988), and as new knowledge is created by collective learning from within the network (Allen 1983). In this sense, a closed network serves to provide and protect access, develop social norms, foster trust, and selectively diffuse information (Coleman 1990). Redundant ties can result in collective action against problems and opportunities, especially when the goals and objectives are part of a shared vision.

Two major problems shared by many businesses today are the globalization of business and the speed of change. These problems present a conundrum in developing benchmark metrics for relational capital for metropolitan areas. The tension resides in the balance between agility and embeddedness in an ecosystem and the determinants of equilibrium between these forces. On the other hand, and in contrast to Coleman's description of the advantages of network closure, Burt's structural hole argument (1992) suggests that networks lacking connections among its separate clusters enjoy significant benefits resulting from the diversity of information and have comparative advantage in obtaining new, non-redundant information through 'weak ties' (Granovetter 1973) and in negotiating more favorable positions in brokering opportunities.

In a fast-changing business climate, access to new information and the ability to negotiate from a favorable position are critical. The high embeddedness of the Parisian enterprise level may constrain the innovation ecosystem of Metropolitan Paris. Similarly, the high embeddedness of Austin's growth and startup levels may lock in a shared vision of global business opportunities based on an Austin perspective, and these could result in missed opportunities in the global ecosystem. In contrast, the low embeddeness of the Twin Cities ecosystem - across all levels - suggests a challenge in creating a shared vision for innovation and change.

\section{Reflections on the IETF process}

This comparative analysis using the IETF Ostinato process (Huhtamäki et al. 2015) provides an opportunity to explore differences and similarities across various levels in three spatially defined innovation ecosystems. Using a data-driven visualization process, the results point to reliance on data, selection of metrics for indicators, and visualizations as key contributions, yet also to opportunities for further exploration and research. The IETF process was applied in this paper for the Triple Helix community. With modifications at each stage of the process, it could be applied for other objectives, 
such as business decisions, policy implications, or innovation program management, and it could include data relevant to government and university relational capital. With the introduction of concepts and metrics for the relational capital of businesses, this analysis contributes to the understanding of institutional relations and their mechanisms to provide new specifications of 'an enterprising state' about businesses, one of the key elements of the Triple Helix model. These insights can inform current programs as well as reveal horizon opportunities.

\section{Reliance on data}

With data openly available on the Internet and curated through social media practices, important contextual insights can be provided to augment program-specific and internal record-keeping and reporting practices. Our utilization of the two data sources and three datasets provided complementary value for the analysis of ecosystem dynamics. While the DAR contains validated alliance information for primarily large, global, and public companies, datasets of EFR and DAR contain information about small, growing companies and startups. In contrast to curated, more limited, and yet timedelayed SDC data source, the IEN data source provides timeliness and access to a wider variety of data, yet which may be handicapped by curation biases (Still et al. 2014b; Basole et al. 2015). Each dataset has its advantages and disadvantages, but used jointly, they triangulate to reveal consistent patterns and create synergistic insights.

Granovetter (1973) differentiates network ties as 'weak ties' - those that are informal and infrequent - and 'strong ties' - those that are close, formal, and regular. The relationships represented by data used for this analysis are biased toward strong ties and may, therefore, omit important relationship capital that exists within other types of community networks. Further, in describing the degree to which actors are involved in cohesive groups that generate normative, symbolic, and cultural structure to behaviors, further elaboration of embeddedness measures could reduce ambiguity and provide actionable insights.

\section{Inferences from snapshots of relational indicators}

This study introduces the use of snapshot network metrics to understand dynamics of relational capital from network metrics in spatially defined innovation ecosystems. As such, it invites further dialogue on the application of network metrics to sociological constructs (such as types of relationships, intensity and depth of relationships, dimensions of community and solidarity) used to study regional innovation. For example, all relationships may not be equivalent, and the degradation of relationships due to graph distance or path independence (Moody and White 2003) should be pursued. Our current measures use cumulative data and treat networks as static - using a snapshot metrics approach. While metrics for whole systems were used in this analysis, caution must be exercised in comparing metrics across levels due to limitations of the type of metrics themselves. Because the realization of any given network is time-dependent (Moody and White 2003), future work could benefit from comparisons over time (Still et al. 2014a) and from including relationship decay over time into the analysis of relational capital.

This analysis used relational capital to infer shared vision, resource flow, and - to some extent - risk tolerance at various levels of innovation ecosystems; the data used in this study reflect direct relationships that are assumed to be intentional. Indirect 
relationships, such as the institutional affiliation or alumni status (Rubens et al. 2011) of a key individual on the boards of two different firms, may also influence decisions and behavior. Studies that have addressed this dimension of relational capital, as well as those that have explored alternative path explanations (Kajikawa et al. 2010) and hierarchical nesting of clusters (Moody and White 2003) have been conducted with different types of data. We are enthusiastic about the application of these constructs to further research using the data sources deployed for this analysis.

\section{Visualizations for storytelling and sensemaking}

There is a growing recognition of the potential value of visualization in the business, strategy, and innovation communities (Tegarden 1999; Yeh et al. 2000; Soukup and Davidson 2002; Huhtamäki et al. 2011). Sensemaking and storytelling support the process of developing a shared vision. Repetition of the narrative contributes to shared vision by both evoking a perception of stability and by hinting at opportunities for change (Dailey and Browning 2013). Storytelling is an integral stepping stone toward shared understanding, which is a prerequisite for innovation ecosystem transformation. The power of alignment for achieving collective action (Labovitz and Rosansky 1997) is especially important in contexts with significant uncertainty. Stories must be carefully chosen to match them to the situation, the scenario, and to organizational objectives (Denning 2004) in order to align purpose and motivate participation.

The visualization of complex data enables decision makers to see patterns, spot trends, identify outliers, and thereby improve comprehension, memory, and decisionmaking (Tufte 1983). The patterns that emerge from large quantities of data can produce insights about the character of phenomena that are represented by the data. Not surprisingly, visual representations of ecosystems are valuable to a diverse set of user groups, including executives who want to understand their firm's competitive landscape, venture capitalists seeking investment opportunities, and policy makers examining innovation dynamics (Basole et al. 2015; Still et al. 2012). An articulated 'wide lens' perspective (Adner 2012) can be shared to establish common ground on which decisions can be based, to create reference points for trade-off decisions, and to lay a foundation for policy. A highly focused 'microscopic lens' can be constructed to gain a deeper understanding of very specific action plans.

\section{Contributions}

Information, talent, and financial resources - essential ingredients for innovation - flow through relationships (Russell et al. 2011). Through coalitions and shared vision developed in the context of such relationships, the transformation of the spatially defined area can be orchestrated. Factors associated with the changes can be analyzed through quantitative and qualitative methods to understand opportunities for intervention in the innovation ecosystem. Quantification of evidence-based indicators helps to establish shared reference points for decision makers. Visualization aids in the discovery, exploration, and communication of complex business ecosystems (Basole et al. 2013a; Basole 2014) and supports storytelling and shared vision.

This paper provides a multiscopic view of the relationship infrastructure among businesses in innovation ecosystems of three metropolitan areas: Austin, TX; Twin Cities, $\mathrm{MN}$; and Paris, France. Using triangulated data, the analysis demonstrates how 
relationship indicators - applied from network metrics can be used to characterize an ecosystem, with descriptions fitting to this specific context. It combines these with visualization to quantitatively and qualitatively analyze and understand complexities of innovation ecosystems and illuminate opportunities for the development of shared vision through interventions and network orchestration. It uses multiple data sources of cumulative data to create compatible datasets for a multiscopic snapshot exploration. Relational metrics for metropolitan innovation ecosystems are operationalized and analyzed at three levels: deals and alliances among established enterprises, executive and financing relationships among growth companies, and founder and angels relationships among startup companies.

Thus, business relationships are examined using the Innovation Ecosystems Transformations Framework, which integrates the Technopolis Wheel, the Triple Helix, and interfirm network approaches to innovation ecosystem studies. The resulting coherent research process offers an approach that relies on an evidence-based and data-driven process for measuring and visualizing the relationship dimensions of innovation ecosystems. The multiscopic application of IETF conceptualizes change as interrelated states in the development or growth (Van de Ven and Poole 2005) of an organization - in this paper, spatially defined as metropolitan areas. The four steps of boundary setting, metrics selection, analysis and visualization, and sensemaking and storytelling form the cyclic Ostinato process (Huhtamäki et al. 2015) for developing shared vision through establishing and questioning a frame through which evidence can be examined. Network metrics and network visualizations reveal existing relationships and distinct patterns of business ecosystem structure in each of the metropolitan areas and provide insights on the engagement, agility, social cohesion, vitality, linking factors, and embeddedness of metropolitan areas, as relational constructs for spatially defined innovation.

\section{Limitations}

The limitations of this exploration offer several opportunities for further research in acquiring and curating data for analysis, identifying and using network metrics for innovation relationships, and utilizing research results and visualizations to accomplish change. Relationships among individuals are one of the key elements - but not the sole factor that defines community, and our analysis identifies metropolitan areas as communities in which relational capital may be an indicator for network orchestration. We recognize that observable relational capital of the business thread in the Triple Helix may include both direct and indirect relationships and that it is one of several mutually interdependent factors.

Evidence-based research responds to the quest for evidence-based intervention, it seeks to answer how an ecosystem emerges and evolves, and its reliability depends strongly on both the quantity and quality of data. The reliability of our results and actionability of insights depend heavily on the nature and quality of the two different but complementary datasets from which samples were obtained. Limitations of institutional and curated data are well established, and caveats on using metrics based on them are understood by both practitioners and researchers. While established datasets may capture large, less frequent events, socially-curated data may capture events that occur in closer time intervals. The nature of such biases, which may be inherent in socially constructed data, are not well documented to date and present an opportunity 
for further study. These observations highlight the importance of setting the context and thoughtfully defining the elements in an innovation ecosystem visualization study.

The validity of our results has benefited from the use of multiple data sources as well as personal knowledge about the ecosystems studied. Even when data-driven analysis shows single directional relationships, it is plausible that a singular event or activity did not necessarily cause the result of interest. Multiple events or activities lying outside the boundary specifications, occurring in a particular sequence, may provide alternative explanations, as in the case of the philanthropic relationships of business leaders in the Twin Cities. Conclusions based on ecosystem models must thus be carefully scrutinized for the possibility of alternative explanations.

Visualization of key players, process, and change direction can be extremely valuable for understanding and analyzing business issues, including strategy, scenario planning, and problem-solving. It can make data more accessible and provide a method for improved communication (Shneiderman 1996). Well-designed visualizations can improve comprehension, memory, and decision-making, critical in the exploration, discovery, and analysis of complex problems (Thomas and Cook 2006). Insights into patterns can often be more easily gained by decision teams with varied analytical backgrounds through the visualization of complex ecosystem data. The challenge, and thereby art and science, of visualization is to create effective and engaging visual representations that are appropriate to the data (Heer et al. 2010) and its use.

Going beyond static snapshots with an interactive visual approach provides avenues for exploration, discovery, and analysis (Thomas and Cook 2006); these can be helpful in understanding the complexities and trade-offs inherent in business ecosystems (Basole 2014; Basole et al. 2015). Many sophisticated visualization techniques exist (Keim 2002). A comprehensive review is beyond the scope of this paper, but interested readers are referred to Heer et al. (2010) who provide examples of salient visualization techniques for a wide variety of purposes. The representation of time units and their alignment across visualizations is an important representational aspect.

Additionally, the visualization of business ecosystems poses particular challenges because the underlying data is large, multi-level, multivariate, and often uncertain (Basole et al. 2015). The visualizations in this paper were developed for a scholarly audience. Adaptations would be needed, following the four-step IETF Ostinato process (Huhtamäki et al. 2015), to conduct an analysis targeted to policy makers or innovation managers. Particularly in visualizing the temporal changes of business ecosystems, node-link configurations are not necessarily unique, and results may be misleading. Patterns in network analysis clearly reveal that there are multiple relational routes to various nodes. Contextual understanding of the ecosystem is essential in drawing insights from patterns revealed in network analysis, and caution is advised in deriving causal statements, as multiple pathways are often visible. Unless guided by an insight-driven iteration of data selection, extraction, and curation, the boundary setting can be artificial and may articulate relationships that are insignificant or misleading for network orchestration.

In many instances, what and how ecosystem data is visualized depends not only on the nature of the data and the question but also on the cognitive abilities and network fluency of the audience. Especially for non-technical stakeholders, the amount of information captured and presented can be overwhelming to the end user. Our analysis by ecosystem level was enabled by the use of several different data sources and our decision to visualize all 
nodes at each level - for an academic audience. For policy makers, business executives, or the general public, an alternate approach might involve integrating data across levels, as in Case Finland (Still et al. 2013b) or filtering the data to highlight patterns in relationships that inform evidence-based decisions, as in the case of EIT ICT Labs (Still et al. 2014a).

Researchers must therefore ensure a balance between detail, abstraction, accuracy, efficiency, perceptual tension, and aesthetics in their complex network visualizations (Segel and Heer 2010). Though we agree with Kohlhammer et al. (2012) that visualization and visual analytics are vital for informed decision-making and policy modeling in a highly complex information environment overloaded with data and information, we do not advocate using network visualizations as the only evidence for decision-making or policy setting. The literacy of decision makers in visual analytics and network metrics is just beginning to emerge. Many managers are not accustomed to reading network visualizations, and the metrics behind them are not yet common knowledge.

\section{Summary and invitations}

In this paper, the Innovation Ecosystem Transformation Model is applied to business relationships at three ecosystem levels in global metropolitan areas and illustrates an evidence-based, data-driven approach for understanding the dynamics of innovation ecosystems and developing shared vision. The IETF model and its application provide both academic and practical contributions.

We present relationship capital indicators, adapted from network metrics, to describe the profile and dynamics of innovation ecosystems. The results establish a foundation for academic exploration of the structure and influence of relational capital in innovation ecosystems, including perspectives on how structural relationships influence access to talent, information, and resources for innovation. The transformational potential of an innovation ecosystem resides in the evolution of the network infrastructure as changes in actors and their relationships occur, accommodating and stimulating innovation. Actors perform roles as arbiters, catalysts, and gatekeepers in open and closed-elite dynamics across time (Powell and Owen-Smith 2013), and such ecosystem changes have been shown to be pervasive, robust, and long-lived (Paquin and HowardGrenville 2013). By studying the relationships on which innovation ecosystems are based, opportunities for guided transformation of an innovation ecosystem, which we call network orchestration, are revealed and can be discussed to build a shared vision for change (Russell et al. 2011).

The concept of network orchestration speaks to a 'discrete influence' in the ecosystem that addresses the interdependencies and flexibility of actors in the network (Rizova 2006), enabling practical coordination of the innovation network and signaling the innovation output (Dhanaraj and Parkhe 2006). Increasingly, networks are intentionally 'orchestrated' or 'engineered' by an organizational actor who recruits network members and shapes their interactions, corresponding to phases of innovation ecosystem building and management (Ritala et al. 2013). Network orchestration, the ability to connect and manage competences across a broad network of relationships, has been recognized as one of the most important meta-capabilities for a networked world (Wind et al. 2008). While boundary setting is an essential step in the IETF process, we recognize that boundedness is a relative phenomenon, and we encourage 
innovation scholars to develop layered and multifaceted approaches to understanding the complex relational structures of innovation ecosystems. Across the constituents of an innovation ecosystem, many critical decisions must be made individually and independently. The speed of change (Yotsumoto 2010) requires zero-time strategies and tactics; it argues against committee review for every decision point or referendum vote for every decision. The shared vision of decision makers networked in relationships enables alignment of sensemaking across their independent decisions to synergize change and transform the present into to a shared future.

\section{Invitation to researchers}

Network orchestration is an understudied process (Parkhe et al. 2006). A better understanding of it may contribute to both scholarly and practical quests (Paquin and Howard-Grenville 2013) to gain 'an integrated understanding of the mechanisms for value creation and capture in the innovation ecosystem context' ((Ritala et al. 2013): p. 246). The application of network metrics to indicators of relational capital for network orchestration holds many opportunities for scholars, policy analysts, and program managers. We encourage the development of improved methods for managing the volume, velocity, and variety of data (McAfee and Brynjolfsson 2012), and we invite researchers to involve their stakeholders in sensemaking and storytelling (Still et al. 2014a). We encourage action researchers to respectfully continue to educate their stakeholders about research methodologies at the same time as they communicate the context, the data, and the analytical processes and present the results in ways that allows decision makers to participate in the exploratory process within the context of relationships based on trust and shared vision.

\section{Invitation to policy makers and their analysts}

Policy makers and practitioners define initiatives based on objectives of their stakeholders. When stakeholders are diverse and outcomes are uncertain, government agencies, consortia, and non-profit organizations frame economic development initiatives with missions that speak to the social benefits as well as the economic benefits. To empower and manage the process of change, program managers, policy analysts, business executives, and entrepreneurs must anticipate opportunities beyond their current line of sight. They must deploy high-impact interventions that anticipate how alternative or concurrent interventions will improve the likelihood of sustainable change.

We invite program managers and policy makers at various levels of innovation ecosystems to explore and embrace the analytical possibilities of combining a variety of data sources for data-driven network visualizations, as well as for other evidence about ecosystems and their actors and interactions. In addition, to allow for faster and deeper insights, we suggest that metrics should include decay as well as formation of relationship links and their representations must move beyond static snapshots. These may include the development of an interactive visualization system using multiple views or a user-driven selection of time units to enable discovery of the temporal nature of ecosystem activities. They may include the exploration of patterns of event sequences between nodes for insights about particular types of relationships (e.g., R\&D alliances) and the time frames for those relationships. 
And finally, we encourage others working in these areas to contact us. Please know that your thoughts, opinions, and efforts will be welcomed and celebrated.

\section{Endnotes}

${ }^{a}$ Examples of lists or rankings include:

- List of most innovative cities described as the world's largest classification and global ranking, with 445 benchmark cities classified and all of the these analyst ranked, based on 162 city indicators (http://www.innovation-cities.com/innovationcities-index-2014-global/8889).

- Metro Monitor: tracking the performance of the 100 largest U.S. metropolitan areas on four indicators: jobs, unemployment, output (gross product), and house prices (http://www.brookings.edu/research/topics/u-s-metro-areas).

- Global MetroMonitor, providing economic growth data (real GDP per capita and employment change) for the largest 300 metropolitan economies worldwide (http://www.brookings.edu/research/interactives/global-metro-monitor-3).

${ }^{\mathrm{b}}$ The City of Austin includes nearly 1 million individuals living in 321 square miles; the Austin Metropolitan Service Area covers an area of 4,286 square miles and includes 1.93 million inhabitants (AustinTexasGov 2014). According to a recent evaluation, Austin, TX is one of the best performing metro areas in the in the list of 100 largest metropolitan areas of US (Brookings 2014). However, it is not included the list of the 300 largest global metropolitan areas, and in popular rankings of most innovative cities in 2014, Austin is ranked number 43 in the world (2ThinkNow 2014).

${ }^{\mathrm{c}}$ A geographic area of approximately 6,364 square miles defines the seven-county area in Minnesota called the Twin Cities Corridor; this includes Minneapolis/St. Paul and suburbs that stretch from St. Cloud to Rochester. Roughly 2.9 million of the State's 5 million people live in this seven-county area (Metro 2013). Its GPD in 2012 was estimated as $\$ 192$ billion (Istrate and Nadeau 2012). Minneapolis metro area's economic performance is ranked number 30 in the list of 100 largest metropolitan areas of US (Brookings 2014); in the global list, its performance is ranked number 209 (Istrate and Nadeau 2012). It has the second highest Fortune 500 companies per capita in the US, which provides an interesting profile for this case study. In the 2014 popular ranking of most innovative cities, Minneapolis-Twin Cities is ranked number 52 in the world (2ThinkNow 2014).

${ }^{\mathrm{d}}$ The 20 administrative arrondissements of Paris proper are home to approximately 2.2 million people. The Greater Parisian metropolitan area, which has a geographic area of approximately 6,631 square miles, is one of the largest population centers in Europe and includes more than 12 million inhabitants. In 2012, its estimated GDP was $\$ 669.2$ billion (Istrate and Nadeau 2012). With a multi-century legacy of culture, arts, tourism, politics, and business, Paris is home to the world headquarters of 32 of the Global 500 companies (Global Fortune 500 by Countries: France 2012). Hence, a global city, Paris is ranked number 5 in the world (2ThinkNow) in the popular rankings of most innovative cities in 2014. However, Paris' score of 262 on the global list of economic performance is relatively low in light of its heritage (Istrate and Nadeau 2012). 
${ }^{\mathrm{e}}$ Data for the deals and alliances ecosystems (shown in Figure 4) do not show deals and alliances with companies outside each metropolitan area.

fWith the 1980's establishment of the Microelectronic Computer Consortium, Austin experienced an influx of scientific and technical personnel; as MCC evolved over 25 years, many of these key individuals stayed in Austin, establishing companies that have leveraged the national and global relational capital - external connections - of those individuals.

${ }^{\mathrm{g}}$ In the Twin Cities Corridor, the social culture for community philanthropy (Zaheer et al. 2010) has a longer tradition than the newer initiatives for innovation. The metropolitan area has a rich history of philanthropy for the arts, celebrated through major social events, creating relationships through which a shared vision at the enterprise level, especially among global enterprises with local headquarters, was developed.

${ }^{\mathrm{h}}$ The 20 administrative arrondissements of Paris proper are home to approximately 2.2 million people. The Greater Parisian metropolitan area, which has a geographic area of approximately 6,631 square miles, is one of the largest population centers in Europe and includes more than 12 million inhabitants. In 2012, its estimated GDP was $\$ 669.2$ billion (Istrate and Nadeau 2012). With a multi-century legacy of culture, arts, tourism, politics, and business, Paris is home to the world headquarters of 32 of the Global 500 companies (Global Fortune 500 by Countries: France 2012). Hence, a global city, Paris is ranked number 5 in the world (2ThinkNow) in the popular rankings of most innovative cities in 2014. However, Paris' score of 262 on the global list of economic performance is relatively low in light of its heritage (Istrate and Nadeau 2012).

\section{Additional file}

Additional file 1: Relational Capital for Shared Vision in Innovation Ecosystems.

\section{Acknowledgements}

Research reported in this paper was partially supported through related research projects funded by TEKES and CapDigital. For interest, encouragement and feedback on earlier versions of this analysis, the authors express deep gratitude to: Camilla Yu, Co-founder of the Innovation Ecosystems Network; Patrick Coquet, Managing Director of CapDigital in Paris; participants at the 2013 IC2 Global Fellows Meeting; and John S. Butler, the University of Texas at Austin.

\section{Author details}

${ }^{1}$ mediaX at Stanford University, Cordura Hall, 210 Panama Street, Stanford, CA 94305-4115, USA. ²Tampere University of Technology, Korkeakoulunkatu 3, 33720 Tampere, Finland. ${ }^{3} \mathrm{VTT}$ Technical Research Centre of Finland Ltd., Kaitoväylä 1, 90571 Oulu, Finland. ${ }^{4}$ Graduate School of Information Systems, University of Electro-Communications, 182-8585 Tokyo, Japan. ${ }^{5}$ Georgia Institute of Technology, School of Interactive Computing and Tennenbaum Institute, 85 Fifth Street NW, Atlanta, GA 30332, USA.

Received: 12 October 2014 Accepted: 12 March 2015

Published online: 04 June 2015

\section{References}

2ThinkNow (2014) Innovation Cities Program. http://www.innovation-cities.com/ retrieved July 7, 2014. Adner R (2012) The Wide Lens: What Successful Innovators See That Others Miss. Penguin Group, NY

Ahuja G (2000) Collaboration networks, structural holes, and innovation: A longitudinal study. Adm Sci Q 45:425

Ahuja G, Soda G, Zaheer A (2012) The genesis and dynamics of organizational networks. Organ Sci 2:434-448

Allen RC (1983) Collective invention. J of Eco Beh 4:1-24

AustinTexasGov (2014). Population and Land Area Study, http://austintexas.gov/demographics, retrieved July 262014.

Barabási AL, Bonabeau E (2003) Scale-free networks. Sci Am 28(5):50-59

Basole RC (2014) Visual business ecosystem intelligence: Lessons from the field. IEEE CGA 34:5

Basole RC, Rouse WB (2008) Complexity of service value networks: Conceptualization and empirical investigation. IBM Syst J 47:53-60

Basole RC, Clear T, Hu M, Mehrotra H, Stasko J (2013a) Understanding interfirm relationships in business ecosystems with interactive visualization. Vis CG IEEE Trans 19(12):2526-2535

Basole RC, Seuss CD, Rouse WB (2013b) IT innovation adoption by enterprises: Knowledge discovery through text analytics. Decis Support Syst 54:1044-1054 
Basole RC, Russell MG, Huhtamäki J, Rubens N, Park H (2015). Understanding mobile ecosystem dynamics: A data-driven approach. ACM TMIS Forthcoming.

Bastian M, Heymann S, Jacomy M (2009). Gephi: An open source software for exploring and manipulating networks. Proc. of the Third Int. AAAI Conf. on Weblogs and Social Media: San Jose, California, USA; May 17-20, 2009.

Brookings Institute (2014) http://www.brookings.edu/research/interactives/metromonitor\#/M12420. Accessed July 28, 2014.

Browning LD, Beyer JM, Shetler JC (1995) Building cooperation in a competitive industry: Sematech and the semiconductor industry. Acad Manag 38:113-151

Burt R (1992) Structural Holes: The Structure of Competition. Harvard University Press, Boston

Burwell SM, Muños C, Holdren J, Krueger A (2013) Next steps in the evidence and innovation agenda. Memorandum to the Heads of Departments and Agencies M-13-17, Washington, DC, USA

Card SK, Mackinlay JD, Shneiderman B (1999) Readings in Information Visualization: Using Vision to Think. Morgan Kaufmann, San Diego, USA

Cartwright D (1968) The Nature of Group Cohesiveness. In: Cartwright D, Zander A (eds) Group Dynamics: Research and Theory, 3rd edn. Harper and Row, New York

Chesbrough H (2003) Open Innovation: The New Imperative for Creating and Profiting from Technology. Harvard Business School Press, Boston

Cohen WM, Levinthal DA (1990) Absorptive capacity: a new perspective on learning and innovation. Admin Sci Quar 35:128-152

Coleman J (1990) Foundations of Social Theory. Harvard University Press, Boston

Cropper S, Ebers M, Huxham C, Smith Ring P (2008) The Oxford Handbook of Inter-Organizational Relations. Oxford University Press Inc., New York, NY

Dailey SL, Browning LD (2013) Retelling stories in organizations: Understanding the functions of narrative repetition. Acad Manage Rev. doi:10.5465/amr.2011.0329

Denning S (2004) Telling tales. Harv Bus Rev 82:122-127

Dhanaraj C, Parkhe A (2006) Orchestrating innovation networks. Acad Manag Rev 31:659-669, doi: 10.2307/20159234

Dougherty D, Dunne DD (2011) Organizing ecologies of complex innovation. Organ Sci 22:1214-1223

Durst S, Poutanen P (2013) Success factors of innovation ecosystems - initial insights from a literature review. Pros. Co-Create 2013. The Boundary-Crossing Conference, Espoo Finland

Eisenhardt KM, Schoonhoven CB (1996) Resource-based view of strategic alliance formation: Strategic and social effects in entrepreneurial firms. Organ Sci 7:136-150

Etzkowitz H, Leydesdorff L (1995) The triple helix of university-industry-government relations: a laboratory forknowledge-based economic development. EASST Review 14(1):14-19

Etzkowitz H, Leydesdorff L (2000) The dynamics of innovation: from National Systems and "Mode 2" to a Triple Helix of university-industry-government relations. Res Policy 29:109-123

Fayyad U, Stolorz P (1997). Data mining and KDD: Promise and challenges. Future Gen Comp Systems, 13:2-3, 99-115, http://www.sciencedirect.com/science/article/pii/S0167739X97000150. Accessed June 13, 2014.

Florida R (2012) The Rise of the Creative Class: And How It's Transforming Work, Leisure, Community and Everyday Life. Basic Books, NY

Freeman LC (2000). Visualizing Social Networks. JoSS 1:1, [np], http://www.cmu.edu/joss/content/articles/volume1/ Freeman.html. Accessed August 31, 2014.

Gibson DV, Butler JS (2014) Sustaining the Technopolis: High-technology development in Austin, Texas. White paper, IC2 Institute, Austin, TX

Gibson DV, Rogers EM (1994) R \& D Collaboration on Trial: The Microelectronics and Computer Technology Corporation. Harvard Business Press, Boston

Gibson DV, Kozmetsky G, Smilor RW (1992) The Technopolis Phenomenon: Smart Cities, Fast Systems, Global Networks. Rowman \& Littlefield Pubs, Inc., Lanham, MD

Global Fortune 500 by Countries: France (2012). Fortune Magazine. fortune.com/global500/, downloaded May 26, 2014

Goldin D, Smolka SA, Wegner P (2010) Interactive Computation: The New Paradigm. Springer, Berlin

Granovetter M (1973) The strength of weak ties. Am J of Soc 78:1360-1380

Green D, Sadedin S (2005) Interactions matter: Complexity in landscapes and ecosystems. Ecol Complex 2:117-130

Gross N, Martin WE (1952) On Group Cohesiveness. Am J Soc 57(6):546-564

Gulati R (1998) Alliances and networks. Strateg Manag J 19:293-317

Gulati R, Nohria N, Zaheer A (2000) Strategic networks. Strateg Manag J 21:203-215

Halinen A, Medlin CJ, Törnroos J-Å (2012) Time and process in business network research. Ind Mark Manag 41:215-223

Heer J, Shneiderman B (2012) Interactive Dynamics for Visual Analysis. Comm ACM 55(4):45-54

Heer J, Bostock M, Ogievetsky V (2010) A tour through the visualization zoo. Comm ACM 53(6):59-67

Huhtamäki J, Russell MG, Still K, Rubens N (2011). A network-centric snapshot of value co-creation in Finnish innovation financing. Open Source Bus Resour March:13-21.

Huhtamäki J, Still K, Isomursu M, Russell MG, Rubens N (2012). Networks of growth: Case of young innovative companies in Finland. Proc. 7th Eur. Conf. Innov. Entrep. Santarém, Port. Sept. 20-21, 2012.

Huhtamäki J, Russell MG, Rubens N, Still K (2015). Ostinato: The exploration-automation cycle of user-centric, process-automated data-driven visual network analytics, in Matei S, Bertino E, Russell MG, Eds. Socio-Computational Frameworks, Tools and Algorithms for Supporting Transparent Authorship in Social Media Knowledge Markets. Springer: NY, Forthcoming.

Hwang WW, Horowitt G (2012) The Rainforest: The Secret to Building the Next Silicon Valley. Regenwald, Los Altos Hills, CA

lansiti M, Levien R (2004) Strategy as ecology. Harv Bus Rev 2:68-78

Istrate E, Nadeau CA (2012) Global MetroMonitor, Brookings, (http://www.brookings.edu/research/interactives/globalmetro-monitor-3), accessed July 20, 2014.

Jackson MO (2008) Social and Economic Networks. Princeton University Press, Princeton, NJ

Kajikawa Y, Takeda Y, Sakata I, Matsushima K (2010) Multiscale analysis of interfirm networks in regional clusters. Technovation 30:168-180 
Katz B, Bradley J, Liu A (2010. Delivering the Next Economy: The States Step Up. Brookings-Rockefeller Project on State and Metropolitan Innovation. Nov. http://www.brookings.edu/ /media/research/files/blogs/2011/2/ 14\%20halls\%20budget/1117_states_next_economy.pdf

Keim DA (2002). Information visualization and visual data-mining. Vis Comp Graph, IEEE Trans. 8;1:1-8.

Klein G, Moon B, Hoffman RR (2006) Making sense of sensemaking 2: A macrocognitive model. IEEE Intel Sys 21 (5):88-92 Kohlhammer J, Nazemi K, Ruppert T, Burkhardt D (2012) Toward visualization in policy making. IEEE Comput Graph Appl 32:84-89

Konno N, Nonaka I, Ogilvy J (2014) Scenario planning: The basics. Special Issue: Strategy, Story and Emergence: Essays on Scenario Planning. World Futures 70(1):28-43

Kozmetsky RG (1993) Breaking the mold: Reinventing business through community collaboration. Paper delivered at MIT Enterprise Forum, Austin, TX

Krackhardt D, Hanson J (1993) Informal networks: The company behind the charts. Harv Bus Rev 71:104-111

Labovitz G, Rosansky V (1997) The Power of Alignment: How Great Companies Stay Centered and Accomplish Extraordinary Things. Wiley, NY

Langford CH, Hall J, Josty P, Matos S, Jacobson A (2006) Indicators and outcomes of Canadian university research: Proxies becoming goals? Res Policy 35(10):1586-1598

Leydesdorff L (2012) The Triple Helix, Quadruple Helix,..., and an N-tuple of helices: Explanatory models for analyzing the knowledge-based economy? J Knowl Econ 3:25-35

Leydesdorff L, Etzkowitz H (1998) The triple helix as a model for innovation studies. Sci Public Policy 3:195-203

Licht AN (2010) Entrepreneurial motivation, culture and the law. In: Freytag A, Thurik R (eds) Entrepreneurship and Culture. Springer, Heildelberg

Liu Y, Slotine J, Barabási A (2011) Controllability of complex networks. Nature 473:167-173

Lott AJ, Lott BE (1965) Group cohesiveness as interpersonal attraction: a review of relationships with antecedent and consequent variables. Psych Bul 64(4):259-309

Marshall A (1920) Principles of Economics, 8th edn. London, Macmillan

McAfee A, Brynjolfsson E (2012) Big Data: The management revolution. Harv Bus Rev 90:60-68

McKinsey (2011). Big Data: The next frontier for innovation and productivity. McKinsey Global Institute, Overall Presentation, October 2011. http://www.mckinsey.com/insights/business_technology/big_data_the_next_frontier_for_innovation. Retrieved January 6, 2014.

Metro Council (2013) Metrostats: Twin Cities Population in 2012. Publication 74-13-024, Minneapolis, MN

Milbergs E (2007). Innovation Vital Signs: Framework Report, An Update. ASTRA- The Alliance for Science Technology Research in America.

Möller K, Rajala A (2007) Rise of strategic nets: New modes of value creation. Ind Mark Manag 36:895-908

Moody J, White DR (2003) Structural cohesion and embeddedness: A hierarchical concept of social groups. Am Soc Rev 68:1,103-127

Moore J (1993) Predators and pray: a new ecology of competition. Harv Bus Rev 71:4, available at http:// blogs.law.harvard.edu/jim/files/2010/04/Predators-and-Prey.pdf (accessed 27 May 2014)

Moore J (1996) The Death of Competition: Leadership and Strategy in the Age of Business Ecosystems. Harper Collins, NY

Mrak M (2000) Globalization: Trends, Challenges and Opportunities for Countries in Transition. United Nations Industrial Development Organization, UNIDO. Vienna, 2000. http://www.unido.org/fileadmin/import/userfiles/puffk/mrak.pdf.

Nahapiet J, Ghoshal S (1998) Social Capital, Intellectual Capital, and the Organizational Advantage. Acad Manag Rev 23:242-266, doi: 10.2307/259373

NESTA (2008). Measuring Innovation: Policy Briefing, MI/25. http://www.nesta.org.uk/sites/default/files/ measuring_innovation.pdf. Retrieved February 12, 2014.

Newman MEJ (2002) Random graphs as models of networks. In: Bornholdt S, Schuster HG (eds) Handbook of Graphs and Networks: From the Genome to the Internet. Wiley-VCH Verlag GmbH \& Co. KGaA, Weinheim, Germany, doi: 10.1002/3527602755.ch2

Nishizawa A (2011) From triple-helix model to eco-system building model. Intl J Technoentrepreneurship 2(3-4):304-323

Noack A (2009) Modularity clustering is force-directed layout. Phys Rev E 79(2):8

North C (2006) Toward measuring visualization insight. IEEE Comput Graph Appl 26(3):6-9

OECD (2001). Innovative Networks: Co-operation in National Innovation Systems. doi:10.1787/9789264195660-en.

OECD (2005) Oslo Manual: Guidelines for Collecting and Interpreting Innovation Data, 3rd Ed. Joint Publication of OECD and Eurostat. http://www.uis.unesco.org/Library/Documents/OECDOsloManual05_en.pdf. Retrieved October 14, 2013.

OECD (2005) Oslo Manual Guidelines for Collecting and Interpreting Innovation Data, 3rd Edition doi:10.1787/ 9789264013100-en, OECD Publishing.

OECD (2014). StatExtracts. http://oecd.org. Retrieved July 31, 2014.

Oliver C (1990) Determinants of interorganizational relationships: Integration and future directions. Acad Manag Rev $15: 241-265$

Oreszczyn S, Lane A, Carr S (2010) The role of networks of practice and webs of influencers on farmers' engagement with and learning about agricultural innovations. J Rural Stud 26:404-417

Ouchi WG, Wilkins AL (1985) Organizational culture. Ann Rev Sociol 11:457-483

Owen-Smith J, Powell WW (2009) Networks, propinquity and innovation in knowledge-intensive industries. Adm Sci Q 54:90-122

Padget JF, Powell WW (2012) The problem of emergence, in Padgett J, Powell WW (Eds) The Emergence of Organizations and Markets. Princeton University Press, Princeton, NJ

Paquin R, Howard-Grenville J (2013) Blind dates and arranged marriages: Longitudinal processes of network orchestration. Organ Stud 34:1623-1653

Parkhe A, Wasserman S, Ralston DA (2006) New frontiers in network theory development. Acad Mgmt J 31(3):560-568

Pentland W (2013). Word's 15 most inventive cities. Forbes, July 9, 2013 http://www.forbes.com/sites/williampentland/ 2013/07/09/worlds-15-most-inventive-cities/.

Podolny JM, Page KL (1988) Network forms of organization. Ann Rev Soc 24:57-76 
Porter M (1990) The Competitive Advantage of Nations. The Free Press, NY

Powell WW, Giannella E (2010). Collective invention and inventor networks. in Hall BH, Rosenberg N (Eds) Handbook of the Economics of Innovation, Vol.1:1 N Holland: Amsterdam.

Powell WW, Owen-Smith J (2013) An open elite: Arbiters, catalysts or gatekeepers in industry evolution? In: Padgett J, Powell WW (eds) The Emergence of Organizations and Markets. Princeton University Press, Princeton, NJ

Powell WW, Koput KW, Smith-Doerr L (1996) Interorganizational collaboration and the locus of innovation: networks of learning in biotechnology. Admin Sci Quart 41(1):116-145

Ritala P, Agouridas V, Assimakopoulos D, Gies O (2013) Value-based network mobilization: A case study of modern environmental networkers. Int J Technol Manag 63:244-267

Rizova P (2006) Are you networked for successful innovation? MIT Sloan Mgmt Rev 3:49-55

Rogers EM (1965) The Diffusion of Innovations. Free Press, NY

Rosenberg D (2002) Cloning Silicon Valley: The Next Generation High-Tech Hotspots. Pearson Education, NY

Rosenkopf L, Schilling MA (2008) Comparing alliance network structure across industries: observations and explanations. Strateg Entrep J 1:191-209

Rubens N, Still K, Huhtamäki J, Russell M (2010) Leveraging social media for analysis of innovation players and their moves. Report Tech, Stanford University

Rubens N, Russell MG, Perez R, Huhtamaki J, Still K, Kaplan D et al (2011) Alumni network analysis. IEEE Glob Eng Educ Conf EDUCON 2011:606-611

Russell MG (1995) Southeastern Minnesota Initiative Fund Regional Development Planning and Evaluation Report. Connect Consultants International, Inc, Minneapolis, MN

Russell MG, Still K, Huhtamäki J, Yu C, Rubens N (2011). Transforming innovation ecosystems through shared vision and network orchestration. Proc. Triple Helix IX Conf: July 2011; Stanford Univ.

Russell MG, Basole R, Rubens N, Huhtamäki J, Still K, (2013a). The transformation of innovation ecosystems in global metropolitan areas: A data-driven perspective. Presentation at 2013 INFORMS, October 8, 2013: Minneapolis, MN.

Russell MG, Rubens N, Huhtamäki J, Still K, Yu C, Basole R (2013b). Orchestrating ecosystem transformations with datadriven network visualizations. Keynote presentation at IC2 Fellows Meeting:Austin, TX;April 25, 2013.

Russell MG, Still K, Huhtamäki J, Yu C, Rubens N, Basole R (2013c). Où seront les enterprises du futur? Keynote Presentation at Futur en Seine, CapDigital: Paris; June 13, 2013.

Saxenian A (1994) Regional Advantage: Culture and Competition in Silicon Valley and Route 128. Harv Bus Sch Press, Boston

Saxenian A (2007) The New Argonauts: Regional Advantage in a Global Economy. Harv Bus Sch Press, Boston

Schilling MA (2009) Understanding the alliance data. Strateg Manag J 30:233-260

Schumpeter J (1942) Capitalism. Socialism and Democracy. Harper \& Bros, NY

Seelos C, Mair J (2012). Innovation is not the Holy Grail. Stanford Soc Innov Rev. Fall. 45-49.

Segel E, Heer J (2010) Narrative visualization: Telling stories with data. IEEE Trans Vis \& Comp Graphics (Proc InfoVis) 16(6):1139-1148

Shneiderman B (1996) The eyes have it: A task by data type taxonomy for information visualizations. Proc IEEE Symposium on Vis Lang, Boulder, CO, pp 336-343

Smilor RW, Wakelin M (1990) Smart infrastructure and economic development: the role of technology and global networks. In: Kozmetsky G (ed) The Technopolis Phenomenon. IC2 Institute, the University of Texas at Austin Austin, TX

Smilor RW, Gibson DV, Kozmetsky G (1988) Creating the Technopolis: High-technology development in Austin, Texas. Journal of Business Venturing 4:49-67

Smith HL, Leydesdorff $L$ (2011). The Triple Helix in the context of global change: Dynamics and challenges. http:// dx.doi.org/10.2139/ssrn.2177331. Retrieved March 10, 2014.

Soukup T, Davidson I (2002) Visual Data Mining: Techniques and Tools for Data Visualization and Mining. Wiley, NY

Still K, Huhtamäki J, Russell MG, Rubens N (2012). Paradigm shift in innovation indicators—from analog to digital. Proc. 5th ISPIM Innov. Forum; 9-12 December, Seoul; South Korea.

Still K, Huhtamäki J, Russell MG (2013a). Relational capital and social capital: One or two fields of research. Proc. ICICKM; Oct. 23-25, 2013; Washington, D.C.

Still K, Huhtamäki J, Russell, MG, Salonen J, Basole R, Rubens N (2013b). Networks of innovation relationships: Multiscopic views on Finland. Proc. XXIV ISPIM Conference; 16-19 June; Helsinki, Finland.

Still K, Huhtamäki J, Russell MG (2014a). Ecosystemic relational capital: framework and process for measuring it. Proc. Triple Helix XIl; 11-13 September; Tomsk, Russia.

Still K, Huhtamäki J, Russell MG (2014b). New insights for relational capital. Proc. ICICKM; 6-7 November; Sydney, Australia.

Still K, Huhtamäki J, Russell MG, Rubens N (2014c) Insights for orchestrating innovation ecosystems: The case of EIT ICT Labs and data-driven network visualizations. Int J Tech Mgmt 66:2/3

Svendsen AC, Boutilier RG, Abbott RM, Wheeler D (2001) Measuring the business value of stakeholder relationships: Part one. CA Inst Chrtd Accts, Toronto, Ontario, CA

Tegarden DP (1999) Business information visualization. Comm of the AIS 1:4

Thomas JJ, Cook KA (2006) A visual analytics agenda. IEEE Comput Graph Appl 26:10-13, doi: 10.1109/MCG.2006.5

Tufte E (1983) The visual display of quantitative information. Graphics Press, Cheshire, CT

Uzzi B (1996) The sources and consequences of embeddedness for the economic performance of organizations: The network effect. Am Soc Rev 61:674-698

Van de Ven AH, Poole MS (2005) Alternative approaches for studying organizational change. Organ Stud 26:1377-1404

Wasserman S, Faust K (1994) Social Network Analysis: Methods and Applications. Cambridge University Press, New York, NY

Weick KE (1995) Sensemaking in Organizations. Sage Publications, Thousand Oaks, CA

Wellman B (1988) Structural analysis: From method and metaphor to theory and substance. In: Berkowitz S (ed) Wellman B. Social Structure A Network Approach. Cambridge University Press, New York, NY, pp 19-61

Welser HT, Gleave E, Fisher D, Smith M (2007). Visualizing the Signatures of Social Roles on Online Discussion Group. J. Soc. Struct. 8. n. pag. https://owl.english.purdue.edu/owl/resource/747/08/ 
Wind J, Fung VKK, Fung W (2008) Network orchestration: Core competency in a borderless world. In: Wind J, Fung VKK, Fung W (eds) Competing in a Flat World: Building Enterprises for a Borderless World. Wharton University Publishing, Upper Saddle River, NJ

Wright W (1997). Business visualization applications. Comp Graph and Appl, IEEE. 17;4:66-70.

Yeh RT, Pearlson K, Kozmetsky G (2000) Zero Time: Providing Instant Customer Value - Every Time. All the Time. Wiley, NY Yotsumoto Y (2010) Americanizing Japanese Firms: The Institutionalization of Corporate Philanthropy and Volunteerism in American Communities. University Press of America, Lanham, MD

Zaheer A, Gözübüyük R, Milanov H (2010) It's the connections: The network perspective in interorganizational research Acad Manag Perspect 24:62-77

Submit your manuscript to a SpringerOpen ${ }^{\circ}$ journal and benefit from:

- Convenient online submission

- Rigorous peer review

- Immediate publication on acceptance

- Open access: articles freely available online

- High visibility within the field

- Retaining the copyright to your article

Submit your next manuscript at $>$ springeropen.com 